\title{
A CASE ANALYSIS OF NEPA IMPLEMENTATION: NIH AND DNA RECOMBINANT RESEARCH
}

\author{
SusAN M. ChalKer* AND Robert S. CATZ**
}

I. INTRODUCTION ............................................. 57

II. The National ENVIRONMENTAL Policy ACT AND DNA

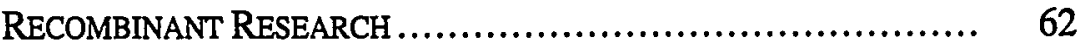

A. "Environment" .......................................... 68

B. "Major Federal Action"' .................................. 72

C. "Significant" ......................................... 73

III. NIH's DRAFT ENVIRONMENTAL IMPACT STATEMENT............. 78

A. The Action ................................................. 79

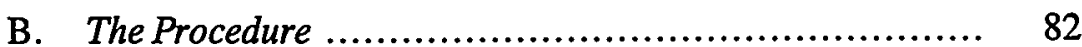

C. The Substance ........................................... 92

1. Lack of Objectivity .................................... 96

2. The Hazards and the Safeguards ...................... 99

3. Inadequate Analysis of Alternatives................. 108

IV. CONCLUSION .................................................. 111

"Can the human mind master what the human mind has made?"

-Paul A. Valery

French Poet and Philosopher

(1871-1945)

\section{INTRODUCTION}

A biological revolution is underway which promises and threatens radical changes in plant and animal life as it now exists. Since 1950, biologists have been quietly at work, largely unnoticed, unravelling the mysteries of life. The new scientific knowledge that has emerged-the knowledge of the molecular basis of heredity-gives scientists the potential power to manipulate the genetic code that determines the physical development of all living organisms. For the first time there exists the technology to cross large evolutionary boundaries and to move genes between organisms that would not, under natural processes, have any genetic contact. This

* Attorney, Civil Division, United States Department of Justice. Professor of Law, Antioch School of Law, 1973-1976.

** Professor of Law, Antioch School of Law.

The views expressed herein are those of the authors and do not necessarily represent the views of any agency of the United States. 
process of gene transference between unrelated organisms is called "recombinant DNA technology." While the pace of scientific achievement has accelerated, government's ability to keep up with it has not.

The most prominent characteristic of recombinant DNA research is its potential for enormous benefit or catastrophic harm. The precise nature of the long- and short-range risks, whether the expected benefits outweigh the anticipated social, philosophical, moral or ecological risks, and whether this research should be undertaken at all, are subjects of current unresolved debate. ${ }^{2}$ Anticipated beneficial impacts include developing cures for cancer and a variety of hereditary diseases such as sickle cell anemia, diabetes, Tay-Sachs disease and phenylketonuria, ${ }^{3}$ producing inexpensive and abundant quantities of oral vitamins and hormones, and providing childless couples with a method of producing offspring. On the negative side, it may be stated that probably no scientific breakthrough since the discovery of nuclear power has such an enormous potential for creating large-scale and irreversible damage to life forms, to future generations and to the biosphere on which we all depend. In addition to the possible accidental creation and dispersion of new destructive bacteria, ${ }^{4}$ the misuse of biological technology portends implications for biological warfare. Moreover, serious moral, ethical and philosophical questions arise when natural human and animal evolutionary processes become the subject of deliberate manipulation which could potentially disrupt the complex and delicate balance among living things in the name of producing "desirable" improvements in humankind. ${ }^{5}$

1. Recombinant DNA technology or "genetic engineering" involves combining a strip of genes from a cell of a higher organism with the genes in a lower organism, such as a bacteria, so that the foreign genes can be studied in a simpler environment. Genes, which are the units that control heredity, consist of deoxyribonucleic acid, DNA. This process technically creates new kinds of living cells. See J. KaTZ, EXPERIMENTATION with Human BeINGS 492 (1972). See generally Green, Genetic Technology: Law and Policy for the Brave New World, 48 IND. L.J. 559 (1973).

2. Fields, Debate Over Genetic Research Spreads Across the Country, Chronicle of Higher Education, Jan. 31, 1977, at 1, cols. 1-3; see Smith, Manipulating the Genetic Code: Jurisprudential Conundrums, 64 GEo. L.J. 697 (1976).

3. Phenylketonuria is a congential deficiency of phenylalanine hydroxylase, which if untreated will produce brain damage and mental retardation. STEADMAN's MEDICAL DICTIONARY 1072-73 (Williams \& Wilkins Co., ed., 23d ed. 1976).

4. Grobstein, A New Genie Is Out of the Bottle, L.A. Times, Aug. 29, 1976, pt. IV, at 5, cols. 1-4.

5. See The Law and the Biological Revolution, 10 CoLUM. J.L. \& Soc. PROB. 47 (1973) (Gaylin, moderator; Callahan, Edgar \& Michels, commentators); Davis, Ethical and Technical Aspects of Genetic Intervention, 285 NEW ENG. J. MED. 1799 (1971); Friedman, The Federal Fetal Experimentation Regulations: An Establishment Clause Analysis, 61 MiNN. L. REv. 961 (1977); Gorney, The New Biology and the Future of Man, 15 U.C.L.A. L. Rev. 273 (1968); Robinson, Genetics and Society, 1971 UTAH L. REv. 487; Vukowich, The Dawning of the Brave New World-Legal, Ethical, and Social Issues of Eugenics, 1971 U. ILL. L.F. 189; Waltz \& Thigpen, Genetic Screening and Counseling: The Legal and Ethical Issues, 68 Nw. U.L. REv. 696 (1973). 
At this point both proponents and opponents of continued and accelerated DNA research concede the speculative nature of both the potential benefits and detriments. This realm of uncertainty regarding consequences, however, is unlikely to persist much longer. The pace of advances in the field have occurred so rapidly that the complex, basic knowledge-the breaking of the genetic code-is available to scientists throughout the world. The capacity to apply this new knowledge will follow in relatively short order ${ }^{6}$ unless the pace of the research and experimentation is abated or circumscribed in some manner by outside forces.

A second significant characteristic of recombinant DNA research in the United States is that although some research is sponsored by private industry and by private educational institutions, the vast majority of it has been funded by the federal government. ${ }^{7}$ The federal commitment has been, and continues to be, the mainstay of molecular biological research in this country. ${ }^{8}$ The largest single federal agency sponsoring genetic research is the National Institutes of Health (NIH), an agency of the U.S. Department of Health, Education and Welfare (HEW). ${ }^{9}$ The system employed by NIH for allocating its limited financial resources among competing researchers, although theoretically providing for input from lay persons, is in practice effectively controlled by the scientific establishment. ${ }^{10}$ Moreover, the NIH regulations and criteria used to review applicants for federally funded research projects are quite broad. ${ }^{11}$ This systematic exclusion of the public from the institutional decision-making processes concerning if, when and how to proceed with DNA research is an additional characteristic of the research effort in the field. ${ }^{12}$ The exclusion is even more pervasive in the

6. Dr. Joseph E. Grady, head of infectious disease research, Upjohn Company, testifying before a Senate science subcommittee, indicated that Upjohn expects marketable by-products of genetic engineering in less than five years. Cohn, "Products" of Genetic Engineering Seen Less Than Five Years Away, Washington Post, Nov. 11, 1977, at A-2, cols. 4-6.

In a recent landmark patent case, In re Bergy, 563 F.2d 1031 (C.C.P.A. 1977), the U.S. Court of Customs and Patent Appeals ruled that Upjohn Company can patent certain forms of life developed in its laboratories. The court's 3-2 decision (Kashiwa, J., concurred in the reasoning and result of the two judge "majority") opened the door for a broad spectrum of food and drug manufacturers to patent processes creating new forms of life. See also In re Chakrabarty, 571 F. 2 d 40 (C.C.P.A. 1978).

7. S. REP. No. 381, 93d Cong., 1st Sess. 4-11 (1973).

8. Id.

9. Id. 19. Biomedical research under the aegis of NIH is of two types: inhouse and grantee. See id. 5-7. The Institute employs over 1000 scientists to engage in full-time research; in addition, millions of dollars are awarded by way of grants to successful applicants.

10. See Parenteau \& Catz, Public Assessment of Biological Technologies: Can NEPA Answer the Challenge?, 64 GEO. L.J. 679, 687 (1976). For an excellent analysis of the DNA recombinant controversy, see Note, Recombinant DNA and Technology Assessment, $11 \mathrm{GA}$. L. REV. 785, 845-60 (1977).

11. 42 C.F.R. $\S 52.13(\mathrm{a})(1976)$.

12. See Bazelon, Technology and the Legal Process, 62 CoRNELl L. REV. 817, 824-25 (1977) (urging greater public participation). 
DNA research efforts undertaken by private educational institutions and by private industry.

Recognition of the hazards associated with recombinant DNA research is not a recent phenomenon. In July 1973, at the Gordon Research Conference on Nucleic Acids, the potential hazards of this research and technology were discussed; those in attendance voted to send an open letter to the Residents of the National Academy of Sciences and the Institute of Medicine suggesting that the Academy "establish a study committee to consider this problem and to recommend specific action or guidelines, should that seem appropriate." 13

The following year, a committee of the National Academy of Scientists chaired by Paul Berg called for a voluntary moratorium on all recombinant activities. The committee also proposed an international meeting of scientists to more thoroughly assess the risks and to devise appropriate guidelines for the safe conduct of DNA research. ${ }^{14}$ An international meeting was held at the Asilomar Conference Center in February 1975 to discuss recombinant DNA research. ${ }^{15}$ Participants at the conference, after reviewing progress in the research and the potential biohazards of the work, concluded that experiments on construction of recombinant DNA molecules should proceed, provided that appropriate containment is utilized. The conference made recommendations for matching levels of containment with levels of possible hazard for various types of experiments. Certain experiments were judged to pose such serious potential dangers that the conferees recommended against their being continued at that present time. ${ }^{16}$

13. House Comm. on SCience \& TeCh., 93D Cong., 2D Sess., Genetic EngineeringEvolution of a Technological Issue, Supp. Report I 8-10, 73 (Comm. Print 1974).

14. The members of the committee published the following resolutions:

First, and most important, that until the potential hazards of such recombinant DNA molecules have been better evaluated or until adequate methods are developed for preventing their spread, scientists throughout the world join with the members of this committee in voluntarily deferring ... [certain] experiments . . . .

Second, plans to link fragments of animal DNAs to bacterial plasmid DNA or bacteriophage DNA should be carefully weighed... .

Third, the Director of National Institutes of Health is requested to give immediate consideration to establishing an advisory committee charged with (i) overseeing an experimental program to evaluate the potential biological and ecological hazards of the above types of recombinant DNA molecules, (ii) developing procedures which will minimize the spread of such molecules within human and other populations, and (iii) divising guidelines to be followed by investigators working with potentially hazardous recombinant DNA molecules.

Fourth, an international meeting of involved scientists from all over the world should be convened early in the coming year to review scientific progress in this area and to further discuss appropriate ways to deal with the potential biohazards of
recombinant DNA molecules. Id. 8 -9.

15. One hundred and fifty-five participants attended, including fifty-five foreign scientists from fifteen countries, four attorneys and representatives of the press. HOUSE COMM. ON Science \& Tech., 94 Cong., 2D Sess., Genetic Engineering, Human Genetics, and CellBiology-Evolution of TECHNOLOGiCal Issues 20, 91-95 (Comm. Print 1976).

16. Berg, Baltimore, Brenner, Roblin \& Singer, Summary Statement of the Asilomar 
Immediately after the conference, NIH adopted the recommendations of the conference as guidelines for research until an advisory committee ${ }^{17}$ had an opportunity to draft more specific guidelines. After meeting three more times, in December 1975 the advisory committee submitted its own proposed guidelines to the Director of $\mathrm{NIH}_{0}{ }^{18}$ and in February 1976 the Director called a special meeting of the advisory committee to review the proposed guidelines. The public was invited to comment and participate in the meeting. After revisions were made in response to the comments at the meeting, the final Guidelines were released and published in the Federal Register; $;{ }^{19}$ the voluntary moratorium on recombinant DNA research ended. On August 23, 1976, NIH, in an effort to comply with the provisions of the National Environmental Policy Act of 1969 (NEPA), ${ }^{20}$ issued a Draft Environmental Impact Statement (EIS) on the DNA Research Guidelines and published the Draft EIS in the Federal Register on September 9, 1976. ${ }^{21}$

This Article contends that, substantively and procedurally, the Draft EIS belatedly issued by NIH is in violation of the letter and spirit of NEPA and that the defects are so fundamental as to render it invalid. The purposes of NEPA have been thwarted, and any improvements that may be made in the final EIS will be of no avail in influencing the reality of continued and accelerated research in the field. This will be so because the major philosophical and ethical issues have never been effectively aired in a public forum, a fact that is unacceptable in an area where the well-being of the public is at stake..$^{22}$ Dramatic legislative intervention, national in scope, is needed; unfortunately, it is too late in the day for NEPA to fulfill its promise.

Conference on Recombinant DNA Molecules, 72 NAT'L ACADEMY SCIENCES PRoc. 1981, 1983 (1975).

17. The Director of NIH established the Recombinant DNA Molecule Advisory Committee to investigate the potential dangers of recombinant DNA research and to recommend guidelines for future projects. 39 Fed. Reg. 39306 (1974).

18. The result was the "Proposed Guidelines for Research Involving Recombinant DNA Molecules," which was referred to the Director of NIH for a final decision in Dec. 1975. HousE COMm. ON SCIENCE \& TECH., supra note 15, at 21-22.

19. 41 Fed. Reg. 27902 (1976).

20. NEPA $\S 102(2)(C), 42$ U.S.C. $\S 4332(2)(C)$ (1970). The issuance of an EIS by NIH was the first time that the agency ever considered its research activities subject to NEPA. See Parenteau \& Catz, supra note 10, at 692.

21. 41 Fed. Reg. 38426 (1976).

22. See generally Asimow, Public Participation in the Adoption of Interpretive Rules and Policy Statements, 75 Mich. L. Rev. 521 (1977); DiMento, Citizen Environmental Litigation and the Administrative Process: Empirical Findings, Remaining Issues and a Direction for Future Research, 1977 Duke L.J. 409; Green, Public Participation in Nuclear Power Plant Licensing: The Great Delusion, 15 WM. \& MARY L. Rev. 503 (1974). 


\section{The National EnVironmental Policy ACt AND DNA RECOMBINANT RESEARCH}

In 1969, in an effort to protect and preserve the quality of the human environment, Congress enacted NEPA. ${ }^{23}$ The ensuing seven years have spawned a proliferation of increasingly lengthy and complex EIS's ${ }^{24}$ as federal agencies have attempted to comply with the numerous court decisions interpreting the Act and, more specifically, with the mandate of the impact statement requirement contained in the Act. While controversy exists as to whether judicial decisions have expanded the scope of the Act beyond legislative intent or whether the courts have done too little to give teeth to the Act in light of the broad evils which the Act was intended to remedy, ${ }^{25}$ there is little question that the environmental consciousness of federal agencies has been raised as they have been forced, at least in form, to take environmental factors into consideration when formulating policies and programs ${ }^{26}$ and when appropriating funds. ${ }^{27}$ However, a review of the voluminous EIS's filed over the last seven years indicates that such statements almost invariably concerned themselves with assessing the impact on the physical environment of easily quantifiable factors, such as the number of persons who would be displaced by the construction of an interstate highway, ${ }^{28}$ or the sewage, heat and water displacement problems engendered by the construction of an office building.

Prior to August 1976, no EIS had been issued by NIH on recombinant DNA research. ${ }^{29}$ Indeed, no evidence exists that the applicability of NEPA to such endeavors had even been considered by the appropriate NIH officials. ${ }^{30}$ In August 1976, however, when the NIH issued and circulated a 1975)).

23. Pub. L. 91-190, 83 Stat. 852 (current version at 42 U.S.C. $\$ \$ 4321-4347$ (1970 \& Supp. V

24. NEPA § 102(2)(C), 42 U.S.C. $\S 4332(2)(C)(1970)$. The EIS must contain the following elements:

(i) the environmental impact of the proposed action,

(ii) any adverse environmental effects which cannot be avoided should the proposal be implemented,

(iii) alternatives to the proposed action,

(iv) the relationship between local short-term uses of man's environment and the maintenance of enhancement of long-term productivity, and

(v) any irreversible and irretrievable commitments of resources which would be involved in the proposed action should it be implemented.

25. See McGarity, The Courts, the Agencies, and NEPA Threshold Issues, 55 TEX. L. REv. 801 (1977).

26. See Note, Program Environmental Impact Statements: Review and Remedies, $75 \mathrm{MICH}$. L. REv. 107 (1976).

27. See Note, The Application of Federal Environmental Standards to the General Revenue Sharing Program: NEPA and Unrestricted Federal Grants, 60 VA. L. REv. 114 (1974).

28. See, e.g. , Sierra Club v. Volpe, 351 F. Supp. 1002 (N.D. Cal. 1972).

29. House COMm. ON SCIENCE \& TECH., supra note 15, at 32.

30. Parenteau \& Catz, supra note 10, at 692 . Between 1970 and 1977 , NIH issued several EIS's. Almost all of these involved simple construction activities, even though the major 
Draft EIS on recombinant DNA research, it embraced for the first time the principle that NEPA's coverage extends to areas of basic research and development. Despite the laudable advance in conceptualization the issuance of the EIS represents, an examination of the purposes and requirements of NEPA indicates that the Draft EIS has dismally failed to meet the high standards required by the Act and has failed to serve its statutory functions as either an aid to internal agency decision-making or as an informational vehicle for the public. ${ }^{31}$

The National Environmental Policy Act of 1969 is an effort to halt the destruction of the environment and to preserve its quality. ${ }^{32}$ It shows that Congress recognizes that human activities, including the actions and nonactions of federal agencies, have had adverse effects on our natural environment, and is committed to the principle that "each person should enjoy a healthful environment." 33 NEPA sets forth three basic purposes:

(1) to declare a national policy which will encourage productive harmony between man and his environment,

(2) to promote efforts which will prevent or eliminate damage to the environment and biosphere and stimulate the health and welfare of man,

(3) to enrich the understanding of the ecological systems and natural resources important to the nation. ${ }^{34}$

"New and expanding technological advances" are explicitly recognized as one factor having a profound influence on the natural environment, ${ }^{35}$ and the legislative history cites many instances where the failure to take environ-

activity undertaken by the agency is biomedical research. One statement did touch upon a more sophisticated environmental problem-a proposal to construct an incinerator for the disposal of hazardous laboratory wastes at the Bethesda, Md. campus of NIH. Interestingly, the decision to build was postponed after the EIS turned up significant problems with the proposed facility.

31. See generally Hanks \& Hanks, An Environmental Bill of Rights: The Citizen Suit and the National Environmental Policy Act of 1969, 24 RUTGERS L. REV. 230 (1970).

32. Other congressional acts evidencing a similar commitment to enhance the quality of the environment, although less extensive in scope, are the Environmental Education Amendments of 1974, 20 U.S.C. $\S \S 1531-1532$ (Supp. V 1975); Water Quality Improvement Act of 1970, 33 U.S.C. $\S \S 1151,1155-1156,1158,1160-1172,1174$ (1970); Air Quality Act of 1967, 42 U.S.C. $\S \S$ 1857-1857l (1970); Environmental Quality Improvement Act of 1970, id. \$\$ 4371-4374.

33. NEPA § 101(c), 42 U.S.C. $\$ 4331$ (c) (1970). This section derives from a provision of the Senate bill, S. 1075, 91st Cong., 1st Sess., 115 Cong. Rec. 19008 (1969), which stated that Congress "recognizes that each person has a fundamental and inalienable right to a healthful environment." Id. \& 101(b), 115 CoNG. Rec. 19008 (1969). The Conference Report states: "The compromise language was adopted because of doubt on the part of the House conferees with respect to the legal scope of the original Senate provision." H.R. REP. No. 765, 91st Cong., 1st Sess. 8, reprinted in [1969] U.S. Code Cong. \& Ad. News 2767, 2768-69.

34. NEPA \& 2, 42 U.S.C. § 4321 (1970).

35. NEPA § 101(a), id. § 4331(a). Other aspects of human activity specifically recognized as having an impact include population growth, high density urbanization, industrial expansion and resource exploitation. 
mental and health concerns into account prior to implementation of innovative technologies resulted in disastrous environmental consequences. ${ }^{36}$ The Act establishes as a national policy the commitment "to use all practicable means . . . to create and maintain conditions under which man and nature can exist in productive harmony." 37 To effectuate this policy it is the responsibility of the federal government to "improve and coordinate Federal plans, functions, programs and resources to the end that the Nation may . . attain the widest range of beneficial uses of the environment without degradation, risk to health or safety, or other undesirable and unintended consequences." 38

Section $101^{39}$ articulates a policy of enlightened substantive values and recognizes the need for improved environmental planning by requiring all agencies to consider values of environmental preservation in their spheres of activity. The section's broad goal is a major first step in the congressional scheme to eliminate shortsightedness in the conduct of human affairs having environmental consequences. It is only the first step, however. Congress went on in section 102 to prescribe a methodology for implementing these substantive concepts to ensure that the stated values are in fact fully respected. ${ }^{40}$ Unlike the substantive policy provisions of the Act, which are flexible and leave room for a responsible exercise of discretion, the "procedural" provisions of section 102 impose non-discretionary obligations and require a strict standard of compliance. They form the very essence of the Act. ${ }^{41}$

The section 102 procedures must be complied with "to the fullest extent possible",42 in making decisions having environmental impact.

36. See generally 115 CONG. REC. 40 (1969).

37. NEPA § 101(a), 42 U.S.C. § 4331(a) (1970).

38. NEPA \& 101(b), id. § 4331(b).

39. NEPA § 101 , id. $\S 4331$.

40. NEPA § 102, 42 U.S.C. $\S 4331$ (1970 \& Supp. V 1975), prescribes a methodology. It does not tell the decision-maker what values to prefer. This provision was not in S. 1075 as it was originally introduced by Sen. Henry Jackson (D-Wash.). As introduced, S. 1075 was intended primarily to authorize the Secretary of the Interior to conduct ecological investigations, and to establish a Council on Environmental Quality. Section 102 was generated in large part by the experience with the Miami jetport, an ongoing controversy during the same period that S. 1075 was under consideration in the Senate. A lesson thought to be learned from that controversy was that the process of coordinating is not a reliable means by which to provide for environmental protection, or indeed to identify the environmental issues, in connection with major public works projects. Instead it seemed necessary to require articulation along the lines provided by section 102. See Brennan, Jetport: Stimulus for Solving New Problems in Environmental Control, 23 U. FLA. L. REv. 376 (1971); Kessler \& Teply, Jetport: Planning and Politics in the Big Cypress Swamp, 25 U. MiamI L. Rev. 713 (1971).

41. Perhaps because of the vagueness of the statutory language, the mandatory nature of the procedural duties, and the courts' view that their reviewing authority is limited, there are few judicial interpretations of the broad substantive provisions of section 101. Most judicial attention has focused on section 102's impact statement requirement.

42. NEPA $\S 102,42$ U.S.C. $\S 4332$ (1970). This strong language in the procedural section should be contrasted with the weaker standard in substantive section 101(b), which requires 
Among the most important are the requirements that every federal agency "utilize a systematic, inter-disciplinary approach"; ${ }^{43}$ make efforts to quantify presently unquantified environmental values and give them appropriate consideration along with economic and technical considerations; ${ }^{44}$ " $r$ recognize the worldwide and long-range character of environmental problems and ... . lend . . . support to initiative . . . and programs designed to maximize international cooperation in environmental improvement"; 45 and "study, develop and describe . . . alternatives to recommended courses of action" involving "unresolved conflicts concerning alternative uses of available resources." 46

In many ways the most important procedural requirement is that every federal agency proposing "legislation and other major Federal actions significantly affecting the quality of the human environment" must issue a "detailed statement" accounting for all of the impacts of the action. ${ }^{47}$ The statement must evaluate any alternatives to the proposed action, ${ }^{48}$ take into account the action's long range consequences, ${ }^{49}$ and delineate the unavoidable adverse consequences of the action. ${ }^{50}$ This justification document, the

agencies to "use all practicable means consistent with other essential considerations." Id. § 4331(b). The difference in approach, apparent from a surface language comparison, is made express in the words of the Senate and House conferees who explained the "fullest extent possible" language as follows:

The purpose of the new language is to make it clear that each agency of the Federal Government shall comply with the directives set out in . . . [section 102(2)] unless the existing law applicable to such agency's operations expressly prohibits or makes full compliance with one of the directives impossible. . . . Thus, it is the intent of the conferees that the provision "to the fullest extent possible" shall not be used by any Federal agency as a means of avoiding compliance with the directives set out in section 102.

H.R. REP. No. 765, supra note 33, at 9-10, reprinted in [1969] U.S. CODE CONG. \& AD. NEwS 2767, 2770 (emphasis added). The Senators' views are contained in "Major Changes in S. 1075 as Passed by the Senate," 115 CoNG. REC. 40417-18 (1969). The Representatives' views are contained in a separate statement filed with the Conference Report, 115 CONG. REC. 40427 (1969).

43. NEPA § 102(2)(A), 42 U.S.C. $\S 4332(2)(A)(1970)$.

44. NEPA $\S 102(2)(B)$, id. $\$ 4332(2)(B)$. "The legislative history indicates that one of the strong motivating forces behind NEPA, and section 102 in particular, was to make exploration and consideration of environmental factors an integral part of the administrative decisionmaking process." City of N.Y. v. United States, 337 F. Supp. 150, 160 (E.D.N.Y. 1972). "Perhaps the greatest importance of NEPA is to require . . . agencies to consider environmental issues just as they consider other matters within their mandates." Calvert Cliffs' Coordinating Committee, Inc. v. United States Atomic Energy Commission, 449 F.2d 1109, 1112 (D.C. Cir. 1971). See also S. Rep. No. 296, 91st Cong., 1st Sess. (1969); 115 Cong. REC. 40416 (1969) (remarks of Sen. Jackson).

45. NEPA § 102(2)(F), 42 U.S.C. $\$ 4332(2)(F)$ (Supp. V 1975).

46. NEPA \& 102(2)(E), 42 U.S.C. $\$ 4332(2)(E)$ (Supp. V 1975).

47. NEPA \& 102(2)(C), 42 U.S.C. \& 4332(2)(C) (1970).

48. NEPA \& 102(2)(C)(iii), id. 4332(2)(C)(iii).

49. NEPA \& 102(2)(C)(iv), id. \$ 4332(2)(C)(iv).

50. NEPA $\S 102(2)(C)(i i)$, id. $\S 4332(2)(C)(i i)$. 
EIS, is the most concrete of the mandatory procedures of section 102 and is the action-triggering keystone of the NEPA edifice.

Although theoretically all the procedural requisites outlined in section 102 must be complied with regardless of whether an agency issues an EIS, ${ }^{51}$ and although the statutory language throughout the Act is sweeping and obscure, judicial assistance for the most part has been sought only with regard to enforcement of the EIS requirement. Even more rarely has judicial intervention been sought to enforce the substantive provisions of section 101.

When an EIS is filed, a procedure must be established to circulate copies to the public, Congress and other federal, state and local agencies, secure the comments of those with special expertise in the subject matter of the statement, solicit the views of the public, file the statement with the Council on Environmental Quality (CEQ) ${ }^{52}$ and ensure that the statement accompany the proposed legislation or action through agency review processes. ${ }^{53}$ It is at this stage, prior to implementation of a policy or program, that deliberations should be most open to the public and decisions about the action subject to public participation and intervention.

The overall purpose of NEPA is to compel federal agencies to consider the environmental consequences of their actions. The purpose of the requirement of a written justification is to provide a practical vehicle for implementing that purpose. The statement informs the public of environmental consequences of and alternatives to proposed actions and enables evaluation, comment and intervention from interested parties outside the agency process who presumably will not be biased with the same self-interest in the particular project as those within the promoting agency who are responsible for its development and stand to gain the most from its adoption. It ensures that environmental considerations are placed before the ultimate decisionmaker-the public-before federal agencies undertake environmentally damaging actions. It opens up technology-dominated decisions to public inspection. ${ }^{54}$ The expectation is that if the public has timely access to all the

51. Hanly v. Mitchell, 460 F.2d 640, 644 (2d Cir.), cert. denied, 409 U.S. 990 (1972); National Resources Defense Council v. Morton, 458 F.2d 827, 834 (D.C. Cir. 1972).

52. CEQ Guidelines, 40 C.F.R. $\$ 1500$ (1977).

53. NEPA \& 102(2)(C), 42 U.S.C. \& 4332(2)(C) (1970).

54. "It is important that we take people into our confidence before the fact rather than after the fact, in order to provide the opportunity for discussion of the many approaches which can bring a catalyst into being." 115 CONG. REC. 40425 (1969) (remarks of Sen. Randolph). There are also examples of instances where well-focused public input has influenced the agency decision-making process. See Andrews, NEPA in Practice: Environmental Policy or Administrative Reform?, in WORKSHOP ON THE NEPA 21, 29-30 (1976) (Report Prepared Pursuant to the Request of the Subcomm. on Fisheries and Wildlife Conservation and the Environment of the House Comm. on Merchant Marine and Fisheries by the Environment and Natural Resources Policy Division, Congressional Research Service, Library of Congress). Robert Cahn cites the 
relevant information it can operate politically, and if need be judicially, to attain environmentally sound policies. ${ }^{55}$

Requiring the statement to be "detailed," to include specifically for each case project an assessment of the environmental costs weighed against the expected benefits-economic, technical, environmental-and to consider the outlined alternatives that would affect the cost-benefit balance ${ }^{56}$ affords some assurance that the agency's own decision-makers will receive and use the information and will incorporate environmental values into their policy-making internal balancing processes at a time before projects are hardened and resources irrevocably committed. ${ }^{57}$ It provides some assurance that all possible approaches to a particular problem will be taken into account and that the most beneficial decision will be made. ${ }^{58}$ Additionally, such a statement constitutes some evidence that the correct decision-making process has taken place and provides a judicially reviewable record against charges of noncompliance with NEPA. Whether the public and agency informational role of the EIS serves or can potentially serve to fulfill its implicit statutory promise to protect the national environmental well-being in the case of DNA recombinant technology will be discussed further.

In light of the letter and spirit of NEPA, particularly its requirement for an EIS at an early stage in agency planning for projects with a potentially significant environmental impact, it is cause for some surprise that in July

example of a toll bridge in San Francisco that was scrapped because of public pressure resulting in the rejection of the EIS prepared for the project. Cahn, Impact of NEPA on Public Perception of Environmental Issues, in WORKSHOP ON THE NEPA, supra, at 62,65. See also 1 CEQ ANN. REP., ENVIRONMENTAL QUALITY 211-12 (1970).

55. There are various avenues open to members of the public to secure environmental redress. They can petition agencies. If that is unsuccessful, they can petition Congress. An impact statement can be the basis for a court attack on agency action under the Administrative Procedure Act (APA) § 10(e), 5 U.S.C. \$ 706(2)(A) (1970). See Andrews, supra note 54, at 28.

56. This does not imply that only environmental factors need be considered but that they should be given weight along with other legitimate factors such as cost and time.

57. See, e.g. , Brooks v. Volpe, 350 F. Supp. 269 (W.D. Wash. 1972), aff'd per curiam, 487 F.2d 1344 (9th Cir. 1973); Environmental Defense Fund v. TVA, 339 F. Supp. 806 (E.D. Tenn.), aff'd, 468 F.2d 1164 (6th Cir. 1972). See also 115 CoNG. REC. 40416 (1960) (remarks of Sen. Jackson). "The requirement to prepare an EIS has had the salutary effect of continually reminding the decisionmaker that environmental factors must be given adequate attention in all phases of planning." National Environmental Policy Act Oversight: Hearings Before the Subcomm. on Fisheries and Wildlife Conservation and the Environment of the House Comm. on Merchant Marine and Fisheries, 94th Cong., 1st Sess. 5 (1975) (statement of Kenneth McIntyre).

58. The lower courts have almost uniformly recognized NEPA's public informational purpose. See, e.g., Scenic Hudson Preservation Conference v. FPC, 407 U.S. 926, 933 (1972) (Douglas, J., dissenting from denial of certiorari); Maryland Nat"l Capital Park \& Planning Comm'n v. United States Postal Serv., 487 F.2d 1029 (D.C. Cir. 1973); Iowa Citizens for Environmental Quality, Inc. v. Volpe, 487 F.2d 849 (8th Cir. 1973); National Helium Corp. v. Morton, 486 F.2d 995 (10th Cir. 1973), cert. denied, 416 U.S. 993 (1974); International Harvester Co. v. Ruckelshaus, 478 F.2d 615, 650 n.130 (D.C. Cir. 1973). 
1976, several years after NIH and other federal agencies began heavily financing DNA recombinant research, not one EIS on such research, nor for that matter any statement explaining why an EIS was considered unnecessary, had been forthcoming. ${ }^{59}$ Apparently responsible officials within the relevant federal agencies were either in blissful ignorance of NEPA or they concluded that NEPA and its EIS requirement were not applicable to scientific research of any type. This posture, retained for so many years without challenge, is indefensible. ${ }^{60} \mathrm{NEPA}$ applies to "major . . . actions significantly affecting . . . the human environment." ${ }^{1}$ As the following discussion will demonstrate, the funding of recombinant DNA research clearly meets each aspect of this statutory threshold.

\section{A. "Environment."}

Section 102(2)(C) raises a threshold question of the meaning of the phrase "human environment." Like the other threshold EIS terms, such as "significant" and "major," the term "environment" is not defined in the Act. The legislative history also fails to provide any definitional clues. ${ }^{62}$ Literally and broadly construed, the term includes every aspect of human life-the social, psychological and spiritual as well as the physical. As a practical matter, however, some limitations must be placed upon the concept; otherwise every intrusion on a person's senses would potentially trigger the impact statement requirement. ${ }^{63}$

59. An agency's threshold determination that no EIS is required for a particular action must be explained in writing, albeit in far less detail than would be necessary in the EIS itself, so as to provide a judicially reviewable record. In Hanly v. Mitchell, 460 F.2d 640 (2d Cir.), cert. denied, 490 U.S. 990 (1972), the court held inadequate the defendant General Services Administration's terse conclusory memorandum concluding that a proposed jail structure in a residential N.Y. neighborhood would not significantly affect the quality of the environment and that therefore a detailed EIS was not required. See also Harlem Valley Transp. Ass'n v. Stafford, 500 F.2d 328 (2d Cir. 1974); Arizona Pub. Serv. Co. v. FPC, 490 F.2d 783 (D.C. Cir. 1974); Citizens Ass'n of Georgetown v. Zoning Comm'n, 477 F.2d 402 (D.C. Cir. 1973); Comment, Judicial Review of a NEPA Negative Statement, 53 B.U. L. REv. 879 (1973); Comment, Negative NEPA: The Decision Not to File, 6 ENVT'L L. 309 (1976).

60. NIH does not itself have published regulations implementing NEPA. The HEW Department manual contains a chapter entitled "Initial Criteria for NEPA." HEW Dep't Manual, $\mathrm{Ch}$. $B(5)-15$ (1972). The guidelines set forth in the Manual are binding upon all agencies within the Department.

61. NEPA § 102(2)(C), 42 U.S.C. $\S 4332(2)(C)(1970)$, establishes certain thresholds below which agencies need not undertake the expense of preparing impact statements. The time and expense of preparing impact statements for every minor action undertaken by every federal agency would clearly outweigh the environmental value of the statements. Attempts to define these thresholds in individual cases accounts for most of the litigation in the NEPA area.

62. See 115 CONG. REC. 29073 (1969) (remarks of Sen. Jackson).

63. Some courts have excluded the social makeup of a neighborhood from the statutory definition. For example, in Nucleus of Chicago Homeowners Association v. Lynn, $372 \mathrm{~F}$. Supp. 147 (N.D. Ill. 1973), aff'd, 524 F.2d 225 (7th Cir. 1975), cert. denied, 424 U.S. 967 (1976), plaintiff sought to enjoin the construction of a court-ordered, federally financed public housing 
Clearly the physical environment was meant to be included. ${ }^{64}$ The real questions are whether anything beyond the physical is encompassed in the term; whether the ephemeral concepts of the cultural, social, economic and aesthetic ought to be included, and whether their inclusion would enhance or detract from the achievement of the purposes for which the Act was promulgated.

It would appear that the goals of NEPA would be most effectively achieved by giving "environment" a broad reading. The sweeping statement of statutory purposes indicates an overall intent to improve the quality of the environment so that human beings might enjoy a healthier, safer and more enjoyable existence. ${ }^{65}$ The specific aims of seeking to "prevent or eliminate damage to the environment and biosphere and stimulate the health and welfare of man" can be effectuated only if "environment" is not construed narrowly. ${ }^{66}$ Recombinant DNA technology, one of the "new and expanding technological advances" recognized by Congress as having an impact on the natural environment, ${ }^{67}$ falls squarely within the policy declarations of NEPA. ${ }^{68}$ The Guidelines of the Council on Environmental Quality, while not dispositive, ${ }^{69}$ are generally given great weight ${ }^{70}$ and support a

project in Chicago. The thrust of plaintiff's claim was that "the social characteristics of the prospective tenants of the housing units [would] have an adverse impact on the quality of the environment," 372 F. Supp. at 148, since a large influx of low-income neighbors would allegedly destroy the middle-class character of the neighborhood and increase crime rates. The court held that action that affects human social sensibilities does not necessarily affect the quality of the environment. $I d$. at 149. The court further held that in any event there was no evidence that the prospective public housing tenants were more likely to engage in antisocial behavior than the other residents of the neighborhood. Id. at 150 .

64. The physical environment encompasses not only those basic natural resources necessary to sustain present and future generations, Breckinridge v. Rumsfeld, 537 F.2d 864 (6th Cir. 1976), cert denied, 429 U.S. 1061 (1977), but also some conditions affecting the quality of life, Hanly v. Mitchell, 460 F.2d 640, 647 (2d Cir.), cert. denied, 409 U.S. 990 (1972).

The bulk of agency EIS's as well as the majority of EIS's involved in litigation concern impacts on the physical environment. This probably reflects the lack of controversy regarding NEPA's coverage of the physical environment.

65. See S. REP. No. 296, supra note 44, at 8; 115 CONG. REC. 40416-17 (1969) (remarks of Sen. Jackson).

66. NEPA $\S 101$ (a), 42 U.S.C. $\$ 4331$ (a) (1970), declares as a national policy the use "of all practicable means ... to foster and promote the general welfare, to create and maintain conditions under which man and nature can exist in productive harmony, and fulfill the social, economic, and other requirements of present and future generations of Americans."

67. See note 35 supra and accompanying text.

68. NEPA § 101(a), 42 U.S.C. § 4331(a) (1970).

69. See Hiram Clarke Civic Club, Inc. v. Lynn, 476 F.2d 421, 424 (5th Cir. 1973); Calvert Cliffs' Coordinating Comm'n, Inc. v. AEC, 449 F.2d 1109, 1112 n.5, 1118 n.19 (D.C. Cir. 1971).

70. See Greene County Planning Bd. v. FPC, 455 F.2d 412, 417 (2d Cir. 1972) ("We would not lightly suggest that the Council [on Environmental Quality] . . . has misconstrued NEPA"). However, the Fifth Circuit has expressed less deference, see generally Sierra Club v. Lynn, 502 F.2d 43 (5th Cir. 1974) and cases cited therein. 
definition broad enough to include this new science. ${ }^{71}$

Most judicial decisions interpreting NEPA have not dealt with the definition of "environment," but those that have tend to conclude that the term includes elements other than land, air and water. In Hanly v. Mitchell,${ }^{72}$ the court rejected defendant General Services Administration's argument that effects such as noise, riots and disturbances, traffic and parking problems attendant upon its decision to construct a jail facility in a residential area were not "environmental" effects within the meaning of NEPA. The court held that although NEPA

contains no exhaustive list of so-called "environmental considerations," . . . without question its aims extend beyond sewage and garbage and even beyond water and air pollution . . . . The Act must be construed to include the protection of the quality of life for city residents. Noise, traffic, overburdened mass transportation systems, crime, congestion and even availability of drugs all affect the urban "environment." 73

The defendant, said the court, must submit an impact statement that discusses, among other factors, the facility's social impact. ${ }^{74} \mathrm{Hanly}$ has been cited by another court in ruling that the Bureau of Prisons' proposal to erect a youth facility in a residential area near a planned elementary school required the preparation of an EIS. ${ }^{75}$ Cases dealing with federally funded housing projects parallel these two jail building decisions in that they emphasize the project's potential effect on the social as well as the physical environment. ${ }^{76}$ Courts have given a similarly broad reading to "environment" in other

71. Concerning the type of "actions" cognizable under NEPA, the Guidelines provide: "[T]he action must be one that significantly affects the quality of the human environment either by directly affecting human beings or by indirectly affecting human beings through adverse effects on the environment." 40 C.F.R. $\$ 15006$ (c) (1977). They also state that "Section 101(b) of the Act indicates the broad range of aspects of the environment to be surveyed in any assessment of 'significant' effect." Id.

The first annual report of the CEQ gives the following definition for "environmental system": "The earth, its surrounding envelope of lifegiving water and air, and all its living things comprise the biosphere . . . [M]an's total environmental system includes not only the biosphere but also his interactions with his natural and manmade surroundings." 1 CEQ ANN. REP., supra note 54 , at 7 .

72. 460 F.2d 640 (2d Cir.), cert. denied, 409 U.S. 990 (1972).

73. 460 F.2d at 647.

74. Id. at 647-49.

75. Tierransanta Community Council v. Richardson, 4 ENvT'L L. REp. 20309, 20310-11 (S.D. Cal. 1973).

76. See Schict v. Romney, 372 F. Supp. 1270 (E.D. Mo. 1974); 42 U.S.C. $\$ 4332$ (1970). Although finding that NEPA generally applies to proposed housing projects, some courts have not required an EIS because the impact was not "significant" enough to require such a statement. See Hiram Clarke Civic Club, Inc. v. Lynn, 476 F.2d 421, 426-27 (5th Cir. 1973); Wilson v. Lynn, 372 F. Supp. 934, 936-39 (D. Mass. 1974). 
varied contexts, ${ }^{77}$ and at least one agency regulation has defined "environment" to include the natural, social and economic environment. ${ }^{78}$

The possibilities for application of recombinant DNA techniques, once perfected, may lead the way to a veritable cornucopia of unforeseen consequences affecting human health-both positively and negatively-and thus trigger the application of NEPA to projects employing these techniques. Human insulin or growth hormone genes could be inserted and their now rare product collected, plants currently unable to break down nitrogen could be conferred with nitrogen-fixing ability and enhanced quantities and quality of plant protein could be genetically introduced into previously recalcitrant hosts. On the other hand, the accidental or deliberate release of newly created pathogenic organisms or tumor-producing viruses could result in widespread incurable new diseases; the deliberate transfer of drug resistance of micro-organisms which do not acquire it naturally could result in rendering current antibiotics ineffective in fighting diseases now under control. To prevent programs that would endanger human health is a clear commitment voiced in NEPA. ${ }^{79}$ Most comprehensive and important experiments with DNA recombinants entail the transference of genetic material between otherwise unrelated species and the artificial crossing of evolutionary boundaries unlikely to occur under natural processes. While precise prediction of resulting evolutionary effects is impossible, since evolution is the outcome of what would often seem to be an unlikely series of events, the diminution of the value of human life-physically and psychologically-is ultimately involved. If NEPA is to be allowed to fulfill its promise to safeguard the "environment and biosphere and stimulate the health and welfare of man" 80 both for the benefit of this generation and "as trustee of the environment for succeeding generations," 81 the reading given the term "environment" must be broad and liberal.

77. E.g., National Helium Corp. v. Morton, 486 F.2d 995, 1003-05 (10th Cir. 1973), cert. denied, 416 U.S. 993 (1974) (economic impact caused by termination of helium purchase contracts); Nader v. Butterfield, 373 F. Supp. 1175, 1179-80 (D.D.C. 1974) (airlines' use of $x-$ ray to examine passenger luggage requires at least "negative impact statement"); $c f$. United States v. Students Challenging Regulatory Agency Procedures (SCRAP), 412 U.S. 669, 675-77 (1973) (ICC order modifying freight rates for transportation of recyclable materials allegedly would discourage use of such materials).

78. 39 Fed. Reg. 38244, 38252 (1974) (United States Forest Service).

79. An intention to protect the health of man is mentioned several times in the Act. Section 2, outlining the purposes of the Act, includes that of "stimulat[ing] the health and welfare of man," NEPA $\$ 2,42$ U.S.C. $\$ 4321$ (1970), and section 101 of the Act declares as one of its goals "attain[ing] the widest range of beneficial uses of the environment without degradation, [or] risk to health or safety." NEPA § 101(b)(3), id. § 4331(b)(3).

80. NEPA \& 2, id. § 4321 .

81. NEPA § 101(b)(1), id. § 4331(b)(1). 


\section{B. "Major Federal Action."}

Underlying the establishment of a "majorness" 82 threshold is the belief that if a project entails only a small investment, the time and expense of preparing and circulating an EIS may be grossly disproportionate to the resources devoted to the project and would outweigh the informational value of the statement. ${ }^{83}$ The term "major" has therefore been applied to the "cost of the project, the amount of planning that preceded it, and the time required to complete it." 84 Agencies are generally not required to, and do not, prepare impact statements for projects that do not require "substantial planning, time, resources, or expenditure." 85 The "majorness" threshold for federal actions ${ }^{86}$ is not the same as the "significance" threshold for environmental effects, ${ }^{87}$ although a few courts have viewed the two as being

82. See Comment, Major Federal Actions Under the National Environmental Policy Act, 44 FordHAM L. REv. 480 (1975); Comment, Environmental Law: What Is "Major" in "Major Federal Action?," 1975 WASH. U.L.Q. 485.

83. " $[T]$ he inclusion [in section $102(2)(c)]$ of the term 'major' raises the obvious inference that not every federal action was meant to be included. Congress evidently intended to exclude from consideration the myriad minor activities with which the federal government becomes involved." Julis v. City of Cedar Rapids, 349 F. Supp. 88, 89 (N.D. Iowa 1972). Many of the truly trivial federal actions are safe from attack simply because of the lack of resources necessary to fight them. The Supreme Court's recent decision in Alyéska Pipeline Serv. Co. v. Wilderness Soc'y, 421 U.S. 240 (1975), which severely limits awards of attorneys' fees to environmental plaintiffs, means that environmental plaintiffs will have to be selective in attacking federal actions.

Most courts agree that NEPA sets a "majorness" threshold. E.g., Jicarilla Apache Tribe of Indians v. Morton, 471 F.2d 1275 (9th Ćir. 1973); Transcontinental Gas Pipeline Corp. v. Hackensack Meadowlands Dev. Comm'n, 464 F.2d 1358 (3d Cir.), cert. denied, 409 U.S. 1118 (1972); Hanly, 460 F.2d at 644; Smith v. City of Cookeville, 381 F. Supp. 100 (M.D. Tenn. 1974); Citizens Organized to Defend the Environment, Inc. v. Volpe, 353 F. Supp. 520 (S.D. Ohio 1972).

84. Hanly, 460 F.2d at 644. See Comment, NEPA, Environmental Impact Statements and the Hanly Litigation: To File or Not to File, 48 N.Y.U. L. REv. 522 (1973).

85. Natural Resources Defense Council, Inc. v. Grant, 341 F. Supp. 356, 366-67 (E.D.N.C. 1972). Two other district courts have adopted this language as a definition of "major." Smith $v$. City of Cookeville, 381 F. Supp. 100, 109 (M.D. Tenn. 1974); Citizens Organized to Defend the Environment, Inc. v. Volpe, 353 F. Supp. 520,540 (S.D. Ohio 1972).

86. A few courts have held that any federal action that significantly affects the environment is ipso facto major, e.g., Monroe County Conservation Council, Inc. v. Volpe, 472 F.2d 693, 698 (2d Cir. 1972); Citizens for Reid State Park v. Laird, 336 F. Supp. 783, 786-87 (D. Me. 1972). "It makes little sense to call a project minor when its environmental effects are significant, because it is just these effects which $\$ 102(2)(C)$ requires to be discussed in the impact statement." F. ANDERSON, NEPA IN THE COURTS 95 (1973).

87. See notes 91-105 infra and accompanying text. NEPA's language and statutory history suggest that Congress wanted to establish separate thresholds. As originally drafted, Section 102(c) of S. 1075 (NEPA's precursor) read as follows: "include in every recommendation or report on proposals for legislation or other significant Federal actions affecting the quality of the human environment." S. REP. No. 296, supra note 44, at 30 . The Senate Committee on Interior and Insular Affairs adopted changes suggested by the Bureau of the Budget which resulted in the language that was ultimately enacted. Id. 29, 30. Clearly, the Committee's first 
synonymous. ${ }^{88}$

Despite the fact that courts consistently have failed to define precisely the point where the amount of resources expended makes the project "major," those courts that have considered the matter have set relatively low thresholds. ${ }^{89}$

In the case of NIH-sponsored DNA recombinant research, the issue of how high or low the standard for determining when an action attains "major" status is largely academic. Whether the standard be high or low, the cost of preparing and circulating an impact statement on the subject will not outweigh the informational value. It is unquestionable that the large amount of money granted by NIH on DNA recombinant research over the past ten years achieves that quantum of expenditures required to elevate it to a major federal action. ${ }^{90}$

\section{C. 'Significant."'}

The term "significant," the threshold degree of environmental impact required to trigger the EIS requirement, is particularly elusive of precise definition. In assessing the significance of a proposed federal action, an agency must evaluate the magnitude of the environmental change that will result from the implementation of that action. The spectrum of potential effects may run a course from de minimis to catastrophic with "significant" lying at some indefinite point in between. Both the absolute and the comparative effects may be required to be considered; a test incorporating

concern was in setting a threshold for the size of federal action requiring an EIS. The environmental threshold came later at the suggestion of the Bureau of the Budget. The change did not, however, take away the original threshold-it simply established another.

88. See Monroe County Conservation Council v. Volpe, 472 F.2d 693 (2d Cir. 1972); Citizens for Reid State Park v. Laird, 336 F. Supp. 783, 787 (D. Md. 1972). See also 33 C.F.R. $\S$ 209.410 (1975).

89. The following cases have held federal actions to be "major": San Francisco Tomorrow v. Romney, 472 F.2d 1021 (9th Cir. 1973) (HUD agreement for changing an industrial park project into a neighborhood development program); Monroe County Conservation Council, Inc. v. Volpe, 472 F.2d 693 (2d Cir. 1972) (payment of $60 \%$ of costs of fourteen million dollar viaduct section of highway project); Sansom Comm. v. Lynn, 382 F. Supp. 1242 (E.D. Pa. 1974) (HUD termination of leases in furtherance of Urban Renewal Project); Forty-Seventh Street Improvement Ass'n v. Volpe, 3 ENVT'L L. REP. 20162 (D. Colo. 1973) (construction of one-mile segment of secondary system highway); Boston Waterfront Residents Ass'n v. Romney, 343 F. Supp. 89 (D. Mass. 1972) (HUD participation in demolition project).

90. Each year over two billion dollars are appropriated for all medical research conducted or awarded by grant by the federal government. S. REP. No. 381, supra note 7 (accompanying the National Research Service Award Act of 1974, 42 U.S.C. \& 289 l-1 (Supp. V 1975)). As of May 15, 1977, NIH had awarded $\$ 23,163,165$ for on-going recombinant DNA research activities to 134 projects, primarily universities. Unpublished Computer Printout on recombinant DNA research prepared and on file with the NIH Office on Recombinant DNA Activities. As of June $15,1978, \$ 43,547,574$ has been awarded to 371 projects. 
the two types of measurement has been suggested by one court. ${ }^{91}$ The proposed action should be reviewed in the light of the extent to which the action will cause adverse environmental effects in excess of those currently existing, and the absolute adverse environmental effects of the action itself, including the cumulative harm that results from its contribution to existing adverse conditions or uses in the affected area. ${ }^{92}$ The first factor involves a comparison of the present state of the environment with its envisioned state after the implementation of the action-a comparison that can be made with some objectivity depending on the certainty of the predictions. ${ }^{93}$ The second test takes account of the fact that particular federal actions may produce impacts that are different in kind from the impacts of similar actions in other contexts. For example, the effects of chemical discharge of a single industrial plant on the water quality of a river may be minor yet the effects of a second chemical discharge of equal magnitude of a second factory further downstream may be more than twice as environmentally significant as the first; a third factory dumping "may represent the straw that breaks the back of the environmental camel." "94

It may be unrealistic to attempt to assess "absolute" effects on the environment, ${ }^{95}$ and even if that were possible, it is doubtful whether, given the current state of our technical knowledge, ${ }^{96}$ environmental harm can be

91. Hanly v. Kleindienst, 471 F.2d 823 (2d Cir.), cert. denied, 412 U.S. 908 (1973).

92. 471 F.2d at $830-31$.

93. The starting point in this comparison test is the present state of the environment. An additional office building in a Manhattan neighborhood already packed with office buildings may not be environmentally significant; constructing an office building in a residential community may be very significant. Hanly, 460 F.2d at 646; accord, First Nat'I Bank v. Richardson, 484 F.2d 1369 (7th Cir. 1973). Since in making its evaluation an agency must focus on the appropriate environmental context, it is important to define this context correctly. The impact of an action may be insignificant if viewed in an overly broad environmental context. "The 'setting' selected should neither be artificially large, thus diluting the actual impact on the immediate area, nor should an involved project or complex of related projects be artifically 'segmented' whereby individually minor impacts are not studied in their cumulative role." Simmans v. Grant, 370 F. Supp. 5, 16 (S.D. Tex. 1974).

94. Hanly, 460 F.2d at $646-47$.

95. An ecosystem is always a mix of good and bad, depending on individual aesthetic tastes. To create an absolute test invites bureaucrats to devise intricate matrices based on point systems that give the tempting cover of objectivity while hiding biases. See, e.g., R. BURCHELL \& D. Listokin, The ENVIRONMENTAL ImPaCt HandBooK 217-20 (1975). The U.S. Army has devised a scheme that gives points to particular types of environmental impacts in particular quantities. The environmental impact of a project is determined by totaling all of the points that a project scores. Army Reg. No. 200-5, Fig. 4, app. C (1976). Types of impacts are defined so vaguely, however, that subjectivity dominates in determining whether a particular project fits into a particular category.

96. R. BuRCHELl \& D. LISTOKIN, supra note 95, at 216-17; I CEQ ANN. REP., supra note 54, at 28-29. Section 102(2)(B) of NEPA requires that agencies develop systems for taking into account unquantifiable values. 42 U.S.C. $\$ 4332(2)(B)(1970)$. The agencies have not come very far toward implementing this section of the Act. 
measured by any objective, unbiased scale of measurement. However, it may also be unnecessary to do so. It would seem that "significance" as a threshold factor could be more rationally, and certainly more simply, determined, if it were given a definition reflecting the underlying informational purposes of the EIS.

If the objective of a detailed EIS is to provide information about potential environmental impacts and alternatives to the promulgating agency, the public, Congress and other interested state and federal bodies in order to provide a basis for policy-makers to make environmentally sound decisions, it would seem that any action whose impact on the environment would be so slight that elaboration of the impacts could never rationally form the basis of a decision on whether to proceed with the proposed action should not pass the threshold test of "significance." An impact statement would not be required in such a case because neither logic nor the law requires a futile, meaningless act. Conversely, if the project would arguably have an impact sufficiently great to provide a reasonable basis for determining whether to proceed with a proposed action, the EIS should be drafted. ${ }^{97}$ That some subjectivity is inherent in making a determination is both unavoidable and acceptable.

Correlating the significance threshold with the underlying objectives of the EIS essentially argues for a low threshold significance test. Such a position has been adopted by many courts, administrative agencies and the Council on Environmental Quality.

The scheme of the National Environmental Policy Act argues for giving "significant" a reading which places it toward the lower end of the spectrum. . . . [T] he statute must not be construed so as to allow the agency to make its decision [to commit resources to a project] in a doubtful case without the relevant data or a detailed study of it..$^{98}$

The Council on Environmental Quality Guidelines indicate that "if there is potential that the environment may be significantly affected, the [impact] statement is to be prepared." 99

97. Evaluating the environmental impact of agency inaction and challenging agency failure to prepare an EIS on the grounds that significant environmental benefits would flow from the action that the agency is refusing to take may pose a more difficult significance issue. As a technical matter, evaluating the environmental benefit of a proposed action should not be much more difficult than evaluating its environmental detriment. As a practical matter, however, convincing a court to force an agency to prepare an EIS detailing the environmental benefit of a neglected action may be difficult.

98. Hanly v. Kleindienst, 471 F.2d 825, 837 (2d Cir. 1973) (Friendly, J., dissenting). See also Students Challenging Regulatory Agency Procedures (SCRAP) v. United States, 346 F. Supp. 189, 201 (D.D.C. 1972) (3-judge court), rev'd on other grounds, 412 U.S. 669 (1973) ("A statement is required whenever the action arguably will have an adverse environmental impact." (emphasis in original)). Judge J. Skelly Wright qualified this by stating that the matter must be fairly arguable. $346 \mathrm{~F}$. Supp. at 201 n.17.

99. 40 C.F.R. § 1500.6(a) (1976). It further states that "proposed major actions, the 
In making its assessment of whether a proposal rises to the level of "significance," an agency must assess the totality of all relevant environmental effects-indirect as well as direct, long-range as well as shortrange. ${ }^{100}$ It cannot segment what would logically constitute a single project into individual components each of which would in itself be insignificant and by so doing avoid EIS compliance. For example, NIH in assessing the environmental magnitude of its decision to fund DNA research efforts, both by the dispersion of grants to outside scientists and by funneling funds for in-house research in the DNA field, must cumulate environmental impacts from all these research activities. It must cumulate its activities over time as well. The effects of all the years of NIH's activities in the funding of DNA recombinant research must be added together before making a determination of significance of the action. Moreover, the impacts of its combined activities in promoting DNA recombinant research must be assessed as against all the relevant environmental variables and ecosystems in order to fashion a total environmental impact. Although this presents some difficulties and although the resulting quantitative estimate will necessarily be subjective, there is a value in attempting to assess the cumulative impact on all the various environmental systems. Anything less would result in an underestimation of significance. This aspect of the cumulation requirement assumes particular importance in the context of DNA recombinant experimentation and technology where the environmental consequences projected by persons knowledgeable in the field touch a great many of our various ecosystems, including such areas as plant, animal and human health, and embryonic development.

Moreover, the nature of our environmental systems is such that actions which may appear insignificant on the surface may cause a chain reaction whose effects reverberate in every corner of our ecosystem and significantly impact on mankind in unsuspected ways.

Ecosystems are characterized not only by their parts but also by the interaction among these parts. It is because of the complexity of the interactions that it is so dangerous to take a fragmented view, to look at an isolated piece of the system. By concentrating on one fragment and trying to optimize the performance of that fragment, we find that the rest of the system responds in unsuspected ways. ${ }^{101}$

environmental impact of which is likely to be highly controversial, should be covered in all cases." Id.

100. The CEQ Guidelines expressly provide for cumulating environmental impacts in order to determine whether an EIS is required. Id. $\S 1500.6(\mathrm{a})$.

101. Holling \& Goldberg, The Nature and Behavior of Ecological Systems, in MANAGing the Environment 31, 32 (A. Neuschatz ed. 1973). See B. Commoner, The Closing CirCle 33 (1972). See also Lapping, Environmental Impact Assessment Methodologies: A Critique, 4 ENVT'L AFF. 123, 125 (1975). "A ripple begun in one small corner of an environment may 
At some point, however, the causal link between the federal action and the environmental impact may become so attenuated that including such effects in an impact statement would create a document of wild conjecture and serve no useful purpose. Some courts have suggested that a "but for" test be adopted to eliminate those consequences that are too remote to trigger the EIS requirement; that is, a proposed action would not be regarded as the cause of an environmental impact if the impact would have occurred without it. ${ }^{102}$ This theory of causal nexus does not appear to be helpful for NEPA analysis; the purposes of tort litigation and the EIS are not similar. The central inquiry in tort litigation is whether the defendant should be held responsible for plaintiff's damages. ${ }^{103}$ NEPA is not concerned with agency liability, but rather with ensuring that agencies consider the environmental effects of their actions and disclose them for public scrutiny. Even though a particular agency action may not forestall particular environmental consequences, those consequences may be relevant to a choice between alternative agency proposals. Therefore, they should be publicly set forth.

A minimum causation test that would be in greater philosophic harmony with the low threshold of "significance" is a likelihood standard. If an agency finds that an environmental result is more likely to occur than not upon implementation of the proposed action, it should be required to prepare an impact statement. This test has been utilized by many courts. ${ }^{104}$ All that

become a wave threatening the quality of the total environment. Although the thread may appear fragile, if the actual environmental impact is significant, it must be considered." Citizens Organized to Defend the Environment, Inc. v. Volpe, 353 F. Supp. 520,540 (S.D. Ohio 1972). See also Minnesota Pub. Interest Research Group v. Butz, 498 F.2d 1314, 1322 (8th Cir. 1974) ("There has been increasing recognition that man and all other life on this earth may be significantly affected by actions which on the surface appear insignificant').

102. The court in Simmans v. Grant, 370 F. Supp. 5, 14 (S.D. Tex. 1974), explicitly adopted a "precipitating cause" approach, encompassing a "but for" test:

To a great extent the determination of whether a project is "major" relies upon the inquiry into whether the federal action, whatever it may be, is the precipitating cause of the resultant environmental impact, regardless of who or what may actually have caused the impact. If "but for" the federal action the impact would not have resulted, then the federal action must be found to be "major."

See Proetta v. Dent, 484 F.2d 1146 (2d Cir. 1973); Duke City Lumber Co. v. Butz, 382 F. Supp. 362 (D.D.C. 1974), aff'd, 539 F.2d 220 (D.C. Cir. 1976); First Nat'l Bank v. Watson, 363 F. Supp. 466 (D.D.C. 1973).

103. W. PROSSER, HANDBOOK OF THE LAW OF TORTS, $\$ 41$, at 236 (1971). See also Note, supra note 10 , at $813-22$.

104. See Minnesota Pub. Interest Research Group v. Butz, 498 F.2d 1314, 1320 (8th Cir. 1974) (plaintiffs need only show "that the project could significantly affect the quality of the human environment." (emphasis added)); Hanly v. Kleindienst, 471 F.2d 823, 838 (2d Cir. 1972), cert. denied, 412 U.S. 908 (1973) (Friendly, J., dissenting) (EIS is required whenever a major federal action will arguably affect the environment adversely); Tierransanta Community Council v. Richardson, 4 ENVT'L L. REP. 20309, 20311 (S.D. Cal. 1973) (NEPA's action-forcing provisions apply when a major federal action has the potential to affect the environment); Students Challenging Regulatory Agency Procedures (SCRAP) v. United States, 346 F. Supp. 189, 201 (D.D.C. 1972), rev'd on other grounds, 412 U.S. 669 (1973) (EIS must be prepared whenever major federal action will arguably have an adverse effect on the environment). 
is required is that one be able to point to a specific harm reasonably likely to result from an agency's actions. ${ }^{105}$ While this is not a precise standard, neither certainty nor scientific accuracy of prediction are required. In an area as complex and novel as recombinant DNA research, where no history or proven effects exist, to ask for any higher standard of predictability before an impact statement is required would be contrary to the environmental well-being sought to be protected under NEPA.

The real problem with DNA recombinant research in relation to NEPA is not really whether an EIS is required-that is, whether such federally financed research efforts constitute a "major" action "significantly affecting the . . . environment" - but when it should be filed. The problem of timing is both complex and crucial. An impact statement filed too late is of little value in fulfilling the goals of the Act. The informational purpose of NEPA is defeated if the statement is prepared after the agency makes critical option-limiting decisions. Once the critical choices are made and resources of time and money expended, an agency is unlikely to change its course because of a subsequent EIS. This is precisely what has occurred in the case of federally sponsored DNA technology. In the analysis of the Draft EIS promulgated by NIH which follows it is argued that the document represents a case of too little too late.

\section{NIH's DRAFT ENVIRONMENTAL IMPACT STATEMENT}

The legal need for an impact statement and controls over recombinant DNA research and experimentation was belatedly conceded by NIH in the summer of 1976 when the agency issued two documents within close proximity of one another. The first, Guidelines for Research Involving Recombinant DNA Molecules, released June 23, 1976, prohibits some types of experiments classified as too hazardous and establishes laboratory biological and physical containment requirements for the conduct of DNA experiments funded by NIH. ${ }^{106}$ The Guidelines were established to "minimize the potential risks" of such research. ${ }^{107}$ The Foreword to the Guidelines announces that the issuance of the Guidelines "is viewed by NIH as a Federal action that may significantly affect the quality of the human environment" and that therefore a Draft EIS pursuant to NEPA had been ordered to be prepared. ${ }^{108}$ The Foreword continues:

105. The likely consequence test is closely related to Professor Calabresi's notion of causal link, which he defines as follows: "There is a causal link between an act or activity and an injury when we conclude on the basis of the available evidence that the recurrence of that act or activity will increase the chances that the injury will also occur." Calabresi, Concerning Cause and the Law of Torts: An Essay for Harry Kalven, Jr., 43 U. CHI. L. REv. 69, 71 (1975).

106. 41 Fed. Reg. 27902 (1976).

107. Id. 38426.

108. Id. 38427. 
[A]Ithough NEPA assumes that such Federal actions will not be taken until the NEPA procedures are completed . . . NIH concluded that the public interest required immediate issuance of the Guidelines rather than deferral for the months that would be required for completion of the NEPA process because the escape of potentially hazardous organisms was more likely in the absence of NIH action. Further, prompt issuance of the Guidelines was believed necessary in order to promote their acceptance by scientists in the U.S. and abroad who do not come under purview of NIH. ${ }^{109}$

On August 19, 1976, the promised Draft EIS was released and circulated to the public, federal agencies, Congress and state and local governments as required by NEPA. ${ }^{110}$ If the recipients were heard to breathe a sigh of relief that the much needed and sought after information regarding DNA recombinant research and technology was at hand in the form of an impact statement, it was premature. Even a brief review of the Draft EIS reveals that it does not have the characteristics and attributes one has come to expect of such statements:

\section{A. The Action.}

The first problem is that the "action" which forms the subject matter of the Draft EIS-the agency's action which it is admitting may "significantly affect . . . the human environment"-is the issuance of NIH's own Guidelines governing the laboratory conditions under which research is to be conducted, rather than, as one would have reasonably expected, the agency's massive funding of DNA recombinant research. The Guidelines, however important, are merely a preventive measure to reduce the potential dangers made possible by the "action" of funding such research in the first instance. The distinction is more than semantic; it is evidence of a fundamental flaw in conception. Interpreted in its worst light, by defining the "action" in such a way and thus orienting the Draft EIS to the environmental impact of the Guidelines and not DNA technology, NIH is able to make a deliberate end run around NEPA's rigorous requirements. Interpreted in a light most favorable to the agency, this definition of "action" reflects a bias which is pervasive throughout and fatally destroys the required objectivity of the document.

Considering the major action to be the issuance of the Guidelines enables NIH to effectively bypass what ought to be the fundamental question of the EIS-whether such research should be funded at all. This question is generally ignored. Indeed, the implicit assumption is that the

109. Id.

110. On November 28, 1977, the Council on Environmental Quality noted in the Federal Register the availability of the Final EIS on the DNA Recombinant Research Guidelines, 42 Fed. Reg. 60588 (1977). The Final EIS Statement would be required to comply with NEPA § 
research will continue on a wide scale. This assumption has an effect of slanting the entire statement towards a favorable decision on the "Guidelines" themselves. Since continued DNA recombinant research is taken as a given, the Guidelines are invariably seen as an improvement over unchecked experiments in unprotected laboratories and as a responsible and cautious move. The framework of the debate then becomes, "Are the Guidelines better than nothing?"; the answer is easy.

One example of the type of distortion that results from defining the "action" narrowly can be found in the section on "Alternatives." Information on alternatives to the proposed action is required under NEPA to be a part of every impact statement; ${ }^{111}$ each reasonable and appropriate alternative action that might avoid or reduce the negative environmental impacts of the "action" should be thoroughly and objectively described and evaluated. ${ }^{112}$ The legislative history stresses the importance of this source of environmental input into the decision-making process. ${ }^{113}$ The first "alternative" to appear in NIH's Draft EIS is stated as "No Action." 114 It is defined as NIH funding of DNA recombinant research with no grant restrictions on the conditions under which the research would progress. ${ }^{115}$ Of course, given the possible grave risks attendant to such research, "no action" thus defined is unacceptable. In little more than one page of analysis NIH concludes that "the 'no action' alternative would not afford adequate protection." 116

Another example can be found in the section on "Description." This section should describe the proposed action in a manner sufficient to enable interested parties to assess the environmental impacts of the activity. NIH's Draft EIS section on descriptions is incomplete. It describes the physical and biological containment measures which make up its Guidelines, but in line with its initial misapprehension of what constitutes the "action," it does not describe the scope and nature of recombinant DNA research being conducted or planned. Nowhere are we provided with the required and needed

102(2)(C), 42 U.S.C. $\$ 4332(2)(C)$ (1970). See 40 C.F.R. $\$ 1500.7$ (c) (1977) (Council on Environmental Quality Guidelines).

111. NEPA § 102(2)(C)(iii), 42 U.S.C. \& 4332(2)(C)(iii) (1970).

112. CEQ Guidelines, 36 Fed. Reg. 7724-25 (1971). This requires the agency to study, develop, and describe appropriate alternatives to recommend courses of action in any proposal which involves unresolved conflicts concerning alternative uses of available resources. A rigorous exploration and objective evaluation of alternative actions that might avoid some or all of the adverse environmental effects is essential. Sufficient analysis of such alternatives and their costs and impact on the environment should accompany the proposed action through the agency review process in order not to foreclose prematurely options which might have less detrimental effects.

113. See S. REP. No. 296, supra note 44, at 21 : "[T] he agency shall develop information and provide descriptions of the alternatives in adequate detail for subsequent reviewers and decisionmakers, both within the executive branch and the Congress, to consider the alternatives along with the principle recommendations." That the impact statement is the proper instrument to provide this focus is recognized by the CEQ. See note 112 supra.

114. 41 Fed. Reg. 48434 (1976).

115. Id.

116. Id. 
information regarding the research itself or the nature and extent of federal funding of such research. ${ }^{117}$ It is important that the public, Congress and other interested parties know the extent of federal support for recombinant technology to date and projected expenditures. From a description of outstanding NIH and other federal grants and the number and amounts of such grants as well as their geographical locations, interested parties could evaluate the extent of research in progress and the need for immediate controls or for partial or total cessation. Such an evaluation would also be of assistance to NIH decision-makers with respect to funding of the expensive containment facilities outlined in the Guidelines. For existing grants, the EIS should explain whether compliance with the Guidelines is required at present in those contracts and whether grantees are complying. The nature and number of pending grant applications proposing DNA experiments should also be disclosed.

An equally serious omission from the Description section, chilling perhaps in its implications, is the failure to mention, much less describe, another of NIH's major actions on DNA recombinant activities-its decision not to regulate the private sector. When NIH drafted the Guidelines which regulate DNA experiments, it made a decision not to regulate nonNIH-supported research, transportation or commercial use of DNA recombinant techniques even though HEW clearly has the authority to regulate all DNA recombinant activities. ${ }^{118}$ The Guidelines provide no guidance for or sanctions against any private sector use-which is where most of the difficulties with this new technology are likely to arise. In all cases where public funds are not involved, a Pandora's box of biohazards has been effectively thrown open. It may turn out that this decision not to regulate may have more impact on the environment than issuance of the Guidelines; much of the environmental damage the Guidelines seek to prevent may be caused by researchers in private industry and other private institutions. While it is recognized that, in a narrow sense, non-NIH research is not activity by a government agency subject to the NEPA provisions, the fact that NIH has been granted authority to regulate such research creates a governmental interest in the research so that its exclusion is a federal "action," which should be the subject of the Draft EIS.119

117. Although NIH is the lead federal agency with responsibility for recombinant DNA research, other federal agencies have heavily funded such research as well. They include the Department of Agriculture, the Department of Defense, the Energy Research and Development Administration (now the Department of Energy) and the National Science Foundation. HousE COMM. ON SCIENCE \& TECH., supra note 15, at 24.

118. Such authority exists under section 361 of the Public Health Services Act, 42 U.S.C. $\S 264$ (1970).

119. NIH presently possesses or is capable of gathering the information it needs to describe the extent and nature of the recombinant DNA activities not covered by the present Guidelines. 


\section{B. The Procedure.}

The second rude awakening occurs when it is realized that, contrary to the mandates of NEPA, the issuance of NIH's Draft EIS occurred after grants had already been awarded for the conduct of DNA recombinant research and after publication of the Guidelines. This cart-before-the-horse approach is a per se violation of NEPA and is violative of the basic policies and spirit underlying the Act. NEPA was enacted to ensure that federal agencies consider and weigh the environmental consequences of their actions along with other relevant factors in a cost-benefit analysis prior to embarking on any major actions with significant environmental impact, and that as part of the decision-making process they consult with the public and other federal, state and local government agencies so that their opinions can be integrated into the process. ${ }^{120}$ Impact statements should be prepared early enough in the decision-making process to aid the policy-makers in their deliberations-that is, before commitments of time, money and prestige have narrowed the range of meaningful options. An EIS should not be "merely a post-hoc environmental rationalization of decisions already fully and finally made." 121

If we consider, and as the NIH should have considered, the agency's action to be its funding of DNA genetic research, then an impact statement drafted years after substantial grants were awarded frustrates rather than facilitates the informational purposes of NEPA. Even if the August 1976 Draft EIS had been a final EIS adequate in all respects, it would still be untimely.

Scientific research, including genetic engineering techniques, proceeds along a path of progress that can be divided into three stages for purposes of analysis. ${ }^{122}$ The first stage is basic research and development. It is here that the goals of the research efforts are enunciated and broadly defined and

In his opinion which accompanied the release of the Guidelines, Dr. Donald Frederickson, the director of NIH, stated that he had met with representatives of other federal agencies and industry to discuss their DNA activities. Partly as a result of these meetings, the Pharmaceutical Manufacturers Association formed a committee to review the possibility of voluntary adoption of the Guidelines by the drug industry. 41 Fed. Reg. 27902 (1976).

120. In this instance NIH did consult with the scientific community in establishing the Guidelines, and the scientific community did engage in a prolonged debate over a moratorium on recombinant DNA research. Although these discussions show a noteworthy concern over the possible implications of the research and represent a conscientious attempt at self-regulation, only by the NEPA process can the opinions of members of the general public be woven into the decision-making process or public policy. See Greene County Planning Bd. v. FPC, 455 F.2d 412, 422 (2d Cir.), cert. denied, 409 U.S. 849 (1972).

121. Greene County Planning Bd. v. FPC, 455 F.2d 412, 422 (2d Cir.), cert. denied, 409 U.S. 849 (1972).

122. Parenteau \& Catz, supra note 10 , at 687. 
applications for projects are processed and grants awarded. In the second stage, enough knowledge has been mastered so that scientists can envision a technology. Further experimentation and testing must occur, however, prior to practical application. Recombinant research is presently situated at this stage. The final and third stage is reached when the developed technology is implemented. Section 102(2)(C) of NEPA addresses the issue of the timing of an EIS only briefly when it states that the statement must "accompany the proposal [for federal action] through the existing agency review processes." 123 Because two recent Supreme Court cases in this area, Kleppe $v$. Sierra Club, ${ }^{124}$ and Aberdeen \& Rockfish Railroad v. Students Challenging Regulatory Agency Procedures (SCRAP) ${ }^{125}$ used language departing from that customarily applied, ${ }^{126}$ the current status of this timeliness provision is somewhat clouded. However, under any of the tests, it is clear that NIH has not been in compliance.

The general case law prior to the two Supreme Court cases had interpreted the provision to mean that an agency must prepare an impact statement prior to the completion of the planning and development stage of a project. ${ }^{127}$ Translated into the context of the progression of DNA technology this would mean that NIH should have issued an EIS at the time it contemplated embarking on the basic research and development. Such a rule makes practical sense. If the statement is to have any realistic chance of affecting the agency's decision it must be available to the policy-makers at a time prior to the hardening and completion of plans. If the statement is not prepared until the implementation stage, although it may have some informational value, it is not likely to substantially affect decisions already crystalized. It is more likely to serve as a post hoc rationalization for the developed technology than as a searching and critical evaluation of the benefits and risks inherent in the proposed technology. ${ }^{128}$ The rule also makes sense in terms of the practical value of the information to the public. The ability of the public to meaningfully participate in the decision-making

123. NEPA § 102(2)(C), 42 U.S.C. \& 4332(2)(C) (1970).

124. 427 U.S. 390,406 (1976).

125. 422 U.S. 289 (1975).

126. See notes $149-54$ infra and accompanying text.

127. See Hill v. Coleman, 399 F. Supp. 194 (D. Del. 1975); Jones v. Redevelopment Land Agency, 3 ENVT'L L. REP. 20,607, 20,608 (D.D.C. 1973); San Francisco Tomorrow v. Romney, 342 F. Supp. 77, 82 (N.D. Cal. 1972), aff'd in part and rev'd in part, 473 F.2d 1021 (9th Cir. 1973); Environmental Law Fund v. Volpe, 340 F. Supp. 1328, 1332 (N.D. Cal. 1972). See also Soil Conservation Service, U.S. Dep't of Agriculture, Guidelines for Preparation of Environmental Impact Statements, 7 C.F.R. \& 650.5(a) (1977).

128. "Bureaucrats develop vested interests in positions adopted at early stages, and it becomes more likely that an EIS prepared at the end of the bureaucratic chain will be nothing more than a post hoc rationalization of prior development." Sierra Club v. Morton, 400 F. Supp. 610, 644 (N.D. Cal. 1975); see Natural Resources Defense Council, Inc. v. U.S. Nuclear Regulatory Comm'n, 539 F.2d 824, 841-42 (2d Cir. 1976). 
process is drastically reduced if the information is made available after the planning is complete, both because the agency will have developed vested interests in having the project continue, and because the legislature and the courts will be less easily moved, except in the most extreme circumstances, to interfere with projects ready for implementation.

In one of the few cases dealing with the timing issue specifically in the context of a scientific research program, the court's opinion is in harmony with the rule evolved by the general case law referred to above. In Scientists' Institute for Public Information v. AEC (SIPI), ${ }^{129}$ the District of Columbia Circuit held that NEPA requires preparation of an environmental impact statement prior to actual implementation of a technology. ${ }^{130}$ The research and development program in question was the development of the Liquid Metal Fast Breeder Reactor (LMFBR), funded by the Atomic Energy Commission (AEC), ${ }^{131}$ which was designed to replace conventional reactors in nuclear power plants with a reactor capable of producing its own enriched uranium fuel. The goal of the AEC program was to enable nuclear plants to breed their own fuel and thus alleviate the fuel shortage problem and eliminate expensive features of the conventional nuclear fuel cycle. The LMFBR, however, would generate a substantial amount of additional high level radioactive waste and foster further proliferation of nuclear plants, each of which would constitute a significant environmental impact. A group of scientists filed suit to compel the AEC to prepare an impact statement prior to full implementation of the program. ${ }^{132}$ The agency refused on the grounds that an EIS was not required for research and development and that assessment of the program's impact at that point would be speculative. ${ }^{133}$ The district court agreed and dismissed the suit. Reversing, the District of Columbia Circuit held, "We . . . tread firm ground in holding that NEPA requires impact statements for major federal research programs, such as the Commission's LMFBR program, aimed at development of new technologies which, when applied, will significantly affect the quality of the human environment." 134 Addressing the ripeness problem, ${ }^{135}$ the court

129. 481 F.2d 1079 (D.C. Cir. 1973). The court's decision did not touch on the degree of public participation required in the agency decision-making process.

130. Id. at 1091.

131. The program was actually under contract to a private laboratory but was funded exclusively by AEC. Id. at 1083 .

132. Id. at 1082.

133. Id. at 1085-86.

134. Id. at 1091 (emphasis added).

135. The court found that the fact that the impact would not be felt for several years was not a controlling factor: "[t]he Act plainly contemplates consideration of both the long- and shortrun implications to man, his physical and social surroundings, and to nature . . . in order to avoid to the fullest extent practicable undesirable consequences for the environment." Id. at 1090 (quoting 36 Fed. Reg. 7724 (1971) (CEQ Guidelines)). 
furnished three reasons for holding that NEPA requires an EIS in certain research programs: research and development is a necessary precondition to implementation of a technology; research and development programs usually require an irrevocable commitment of resources, thus causing the balance of environmental, social, economic and other costs and benefits to shift in favor of application; and the general policy of NEPA and its legislative history demonstrates the congressional concern over uncontrolled technological development. ${ }^{136}$ The court did allow the agency some discretion in deciding when to prepare the statement ${ }^{137}$ and directed the agency to consider at least four factors in judging when to draft an EIS: the likelihood that the technology will become commercially feasible, and if so, when; the amount of information available to predict environmental harm; the amount of resources which are being irretrievably committed to the program and any options being foreclosed; and the severity of possible environmental effects. ${ }^{138}$ By weighing these factors, an agency is enabled to strike a balance and arrive at a point in time that is not too early in the development process to prevent the EIS from containing meaningful information, nor too late in the process to keep the EIS from having a meaningful effect on the agency's actions. ${ }^{139}$

If the SIPI timing analysis is applied to NIH's DNA recombinant research and development program, it is seen that an impact statement should have been prepared at the time NIH made the decision to divert money, time and scientific resources into genetic engineering techniques and thereby take those resources away from other related research programs; that is, at the time grant applications were initially approved in bulk for such research. Under the SIPI test, that point was reached and an impact statement on DNA research should have been drafted several years ago.

The first factor, the feasibility of commercially applying the technology in society, is not, and was not even three years ago, a subject of real dispute among scientists. ${ }^{140}$ The pace of the science is accelerating so rapidly that scientists who a few years ago predicted that application was ten or twenty years away were saying more recently that application of the new methods was closer to five years hence. ${ }^{141}$ Latest developments have ren-

136. 481 F.2d at $1088-90$.

137. Id. at 1092 .

138. Id. at 1094.

139. Id. To further aid the agencies with the timing problem, the court suggested that the agencies engaged in long term technological research and development programs should develop procedures for regular, even annual, evaluation of programs to determine whether the time for drafting an EIS had arrived. Id.

140. The massive amounts of money being pumped into this program also indicates widespread confidence that the program will succeed. See note 90 supra and accompanying text.

141. See note 13 supra and accompanying text. 
dered even these predictions too conservative. The day may in fact have arrived. Dr. Stanley Falkow of the University of Washington has recently announced the creation, through DNA research, of a vaccine to attack scours-a severe and often fatal diarrhea of young pigs and cattle and one of American agriculture's costliest diseases. ${ }^{142}$ At the same time he indicated a belief that through the same gene manipulating methods a vaccine against human diseases would soon be marketable. Two doctors at universities in California are approaching success in their efforts to synthesize the insulin gene and are seeking a patent on what they believe could be wide commercial applications. ${ }^{143}$ Commercial application of DNA recombinant technology is on the brink of reality; it was far from being wild-eyed prophecy three years ago.

The second SIPI factor-whether the amount of current information on the possible harm from application of the technology is sufficient to allow the agency to make predictions of environmental harm-is abundantly satisfied in DNA technology, and has been for at least the last three years. Although predictions are necessarily speculative, since no body of practical experience has amassed in this young science to provide a practical guide to the future, they are also not the result of crystal ball gazing. Numerous documents written and published by scientists, within and outside government, provide a convincing and significant body of information on the reasonably foreseeable harmful environmental impacts of applied DNA technology. Scientists were sufficiently persuaded of and concerned about the potential for harm in the application of these new techniques that they agreed to impose an unprecedented moratorium on their own research efforts, although individually most had much to gain from unfettered experimentation. Scientists at NIH had amassed enough hard data in the field well before the Guidelines were written to devise a physical and biological containment system based on a thirteen-tier classification of risks. ${ }^{144}$ Scientific predictions had reached well beyond the level of uninformed generalities; there was no reason why NIH could not have explored, based on the available evidence, such foreseeable dangers in an environmental impact statement.

There are sizeable irretrievable commitments of resources taking place in the program - the third factor to be considered in the SIPI analysis. Each

142. Cohn, Gene Study Booming, Despite Fears, Washington Post, Mar. 6, 1977, at A-22, col. 1.

143. Id. at A-22, col. 2, The doctors are Dr. Herbert Boyer of the University of California at San Francisco and Dr. Stanley Cohen of Stanford University. Seven major drug companiesHoffmann-La Roche, Upjohn, Eli Lilly, Smithkleine Merck, Abott and Miles Laboratorieshave started or plan experiments. Id.

144. See 41 Fed. Reg. 27902-21 (1976). 
year over two billion dollars are appropriated for all biomedical research, ${ }^{145}$ which exceeds the 100 million dollars per year held to be sufficient and quite "sizeable" in SIPI. ${ }^{146}$ By any standard of measurement, absolute or relative, this quantum of resource commitment is sizeable and, in a world of finite budgets, it forecloses or at least retards the commitment of resources to other related technologies with similar objectives of disease prevention and health care, such as cancer and heart disease research.

The final SIPI balancing consideration is the severity of possible effects of the research. Anticipated effects of DNA recombinant techniques are among the most significant and most controversial of all federal programs and have been analogized on many occasions to the harmful environmental impacts of nuclear technology. The unique and unprecedented environmental hazards envisioned include the creation of novel life forms that could usher in epidemics of world-wide proportions and upset the delicate ecological balance of our total systems. ${ }^{147}$ Moreover, if an error were to be made, cessation of recombinant DNA experiments would in no sense ensure that the diffusion of the hazardous agent would cease. Recombinant molecules have the Sorcerer's apprentice-like capacity for unlimited proliferation. This is not to say that there is certainty regarding either the possibility or the severity of these environmental impacts of the program. Recently groups of scientists have come forward with the claim that the hazards have been exaggerated; others firmly believe that the research is proceeding too rapidly and that the possible dangers are still frightening. ${ }^{148}$

145. S. REP. No. 381, supra note 7, at 19. HEW-funded biomedical research comprises more than $62 \%$ of all federally funded research and more than $40 \%$ of all the biomedical research conducted in the United States. Friedman, supra note 4, at 962 . See also Budget of the U.S. Government, Fiscal Year 1977, App. 330-31; Div. of Public Information, NIH Almanac 11735 (1976) (DHEW Pub. No. NIH 76-5).

146. $481 \mathrm{~F} .2 \mathrm{~d}$ at 1098.

147. Cohn, supra note 6, at A-2, col. 4, which quotes Dr. Arthur Schwartz of the University of Michigan: "Any new technology has a significant probability of going awry and with hundreds of scientists doing DNA research, there will be thousands of incidents per year in which carelessness or the unexpected could cause trouble."

148. Cohn, supra note 142, at A-22, cols. 2-3. Some of the same scientists who called new forms of genetic engineering a "possible danger" are now saying that the risks seem less than they believed. For example, a Letter from Dr. Sherwood Gorbach of Tufts University to NIH (July 15, 1977) (copy on file with the DUKE LAw JouRNAL), signed by 37 doctors and researchers "unanimously" concludes that the danger of runaway epidemics from the bacteria now being used in DNA experiments has proved virtually non-existent. Another 137 scientists have written an open letter to Congress saying "exaggerations of the "hypothetical hazards' have gone far beyond any reasoned assessment." "The experience of the last four years," they state, including many laboratory experiments, has shown no "actual hazard."

It is difficult to be persuaded on the basis of so limited an experimental foundation that we are all safe from danger. The fact that fortunately no tragedies have occurred in four years is not persuasive authority for the proposition that accidents and deliberate misuse of the technology will not occur in the future. It may also be possible that these downplaying reactions were motivated by the fact that Congress has under consideration, and may be about to pass, 
One of the functions of an impact statement is to point up these uncertainties and differences of opinions where they exist. If an impact statement had been properly and timely filed, public input could have been received and utilized in a resolution of the issues.

Although the two recent Supreme Court pronouncements on ripeness in the context of NEPA are more restrictive and mechanical in approach than the earlier appellate case law, NH nevertheless would have been required, under these cases, to have issued an impact statement at least by August 1977 , and probably some years earlier. According to the Supreme Court, the earliest time that NEPA requires an EIS is the point at which the project reaches the status of a "proposal." In Aberdeen plaintiffs argued that an EIS should have been prepared prior to an ICC hearing on the request of the railroads for permanent across-the-board rate increases. Justice White, writing for the majority, disagreed, reasoning that the statutory requirement that an impact statement "accompany the proposal through agency review process" 149 means that the agency's feelings about a program must have jelled into an actual proposal before the impact statement is required. ${ }^{150}$ Therefore, only the Commission's formal report on the proposed rate, issued after the hearing, amounted to a proposal. The mere hearings did not. ${ }^{151}$ Although the Court did not elaborate upon the meaning of the word "proposal," in Kleppe it concluded that the term meant more than mere contemplation. ${ }^{152}$ In that case plaintiff conceded that no formal proposal existed for

legislation that would impose rules the scientists now fear would cripple American science and their own particular ambitions.

This may be a more drastic reaction than they had bargained for from their initial publicized cries of alarm about the repercussions of the new genetic science. They may be particularly distressed at some sections of pending Senate and House bills which provide for fines of either $\$ 10,000$ (in the Senate version), S.1217, 95th Cong., Ist Sess. (1977), or $\$ 5,000$ (in the House version), H.R. 7897, 95th Cong., 1st Sess. (1977), for each day they violate the proposed regulations. However, even those who criticize pending legislation as being too restrictive are not advocating totally unfettered experimentation with recombinant DNA molecules. Rather, the disagreements revolve around how much restriction is necessary.

149. 422 U.S. at 320 (quoting NEPA $\S 102(2), 42$ U.S.C. $\$ 4332(2)$ (1970) (emphasis added by Court)).

150. "[T] $]$ he time at which the agency must prepare the final 'statement' is the time at which it makes a recommendation or report on a proposal for federal action." 422 U.S. at 320 (emphasis by Court). The Court reiterated this statement in Kleppe, 427 U.S. at 406.

151. 422 U.S. at $320-21$.

152. 427 U.S. at 406 . In explaining its narrow definition of "proposal" the court stated that "[t]he procedural duty imposed upon agencies by this section is quite precise, and the role of the courts in enforcing that duty is similarly precise." Id.

Justice Marshall, in his dissent, disagreed:

A statute that imposes a complicated procedural requirement on all "proposals" for "major Federal actions significantly affecting the quality of the human environment" and then assiduously avoids giving any hint, either expressly or by way of legislative history, of what is meant by a "proposal" or by a "major Federal action" can hardly be termed precise.

Id. at 420-21 (Marshall, J., dissenting). 
the Department of Interior's and other agencies' plans to regulate the exploitation of coal-related resources in the Northern Great Plains Region. Since no proposal existed, no impact statement was needed. ${ }^{153}$

Adherence to the Supreme Court's holdings in Aberdeen and Kleppe would seem to relieve NIH of the obligation to have prepared an EIS on DNA research and development activities until after its formal action of approving grants, ${ }^{154}$ rather than at the time it was considering various applications for research grants as SIPI and lower court decisions would seem to suggest. There are problems that will arise in applying Aberdeen and Kleppe. Because statutes generally do not specify an identifiable procedural step in which agencies propose actions prior to implementing them, a mechanical search for the EIS-triggering word "proposal" could provide a method for agencies so inclined to circumvent the requirements of NEPA. All they would have to do is avoid using the term "proposal." It is unlikely the Court intended such a result; rather it would seem that the Court meant for lower courts to retain some flexibility to give some force to the term "proposal" and give it a definition related to agency conduct within individual statutory schemes and related to the underlying informational policy purposes of the Act. Such an interpretaion would likely yield the same practical result as that occurring under SIPI and the generally evolving case law. Even applying Aberdeen and Kleppe strictly, NIH was in violation of NEPA when an EIS was not issued at the time the agency formally approved grant applications for DNA molecular research. The formal approval would be tantamount to a "proposal."

Moreover, accepting NIH's premise that the subject matter "action" of the Draft EIS ought to be its Guidelines does not save the agency from being in violation of NEPA. The issuance of the impact statement two months after the Guidelines became effective is a per se violation of the Act. ${ }^{155}$ The

153. Id. at 414-15.

154. Aberdeen and Kleppe might seem to suggest another point in time when NIH was required to issue an EIS. It would seem that for federal projects that require a specific appropriation from Congress, the appropriations request would be a clearly "defined" proposal. But most actions, including DNA research projects, do not receive individual appropriations. In fact, in NIH's budget Congress grants the agency the appropriation before the Institute receives and processes applications for specific projects. Requiring NIH to file an impact statement at the appropriations stage not only would be burdensome and impracticable but also would not allow evaluation of particular programs such as recombinant DNA research and development.

155. Moreover, the procedure also viplates the Administrative Procedure Act, 5 U.S.C. § 553 (1970). The Guidelines are federal regulations. Under the APA's informal "notice and comment" rulemaking procedure, agencies must publish notice of "proposed rules," including either their substantive terms or a description of the subjects and issues involved. This gives interested persons a chance to submit written comments and to attempt to influence the rulemaking. Federal regulations are normally not effective until they have been published in the Federal Register with this period for comment. The Guidelines became effective on June 23, 1976; they were not published in the Federal Register until July 7, 1976. 
Guidelines are proposed rules and like all proposed rules they constitute a "proposal for federal action." NIH concedes its "action" passes the NEPA thresholds that make it a "major federal action significantly impacting on the quality of the human environment." An impact statement is therefore necessary and the section 102(2)(C) timing requirement-that the statement must "accompany the proposal through the existing agency review processes"156_becomes operable. In the case of a proposed rule such as the Guidelines, this would mean that the impact statement must accompany the proposal for the Guidelines throughout the informal rulemaking process. ${ }^{157}$ In pinpointing the exact moment in time when the EIS would be required to be issued, the informational purposes of the statement should be considered; the EIS can and should provide important information in this procedural context in much the same manner as it serves to provide the public and the agency with data in the context of policy actions such as the funding of research and development. The timing of the statement should aid the agency in its substantive decision on whether to adopt the proposed rule, and it should facilitate direct citizen participation. If statement preparation and rule formulation occur together, the added effort spent in preparing the EIS should not unreasonably tax agency resources.

Using this analysis, an impact statement on the Guidelines would have been most meaningful if it had been issued during the period from March 1974 to December 1975, during which the NIH Advisory Committee on Recombinant DNA was meeting and developing the proposed Guidelines. ${ }^{158}$ The Guidelines were submitted as a proposal to the Director of NIH in

156. NEPA § 102(2), 42 U.S.C. § 4332(2) (1970).

157. Some agencies have recognized this clear duty. See, e.g., Coupland v. Morton, 5 ENVT'L L. REP. 20,505 (E.D. Va.), aff'd per curiam, 5 ENVT'L L. REP. 20,507 (4th Cir. 1975) (Department of Interior's preparation of EIS prior to implementing regulations restricting the use of motor vehicles in Back Bay National Wildlife Refuse satisfies requirements of NEPA).

The AEC requires an impact statement for any amendment to rules governing licensing and regulation of nuclear fuels and by-products. 10 C.F.R. $\$ 51.5(\mathrm{a})(1)-(10)(1977)$. A representative of HUD has recognized that the agency's policy regulations are subject to review for NEPA compliance. National Environmental Policy Act Oversight, supra note 57, at 93 (comments of Richard Brown). At least one court has accepted the notion that an impact statement must accompany major rulemaking proposals that significantly affect the environment. In Nader $v$. Butterfield, 373 F. Supp. 1175 (D.D.C. 1974), the FAA had circulated a nonpublic memorandum to regional offices prescribing criteria and standards for $\mathrm{X}$-ray baggage inspection. Nader sued FAA, arguing that the required notice and comment rulemaking procedure had not been utilized and for an injunction requiring the agency to prepare an EIS prior to adoption of the policy as a rule. The court invalidated the $\mathrm{X}$-ray policy because the implementation procedure was unlawful under the APA. Id. at 1179. Furthermore, the court held that before the FAA promulgated the policy through notice and comment rulemaking it should either prepare a final EIS or convincingly demonstrate with a statement of rationale that the new rule would not significantly affect the quality of the human environment. Id. at 1180 .

158. See note 18 supra and accompanying text. 
February 1976 at a special meeting of the committee, in which the public was allowed to comment and participate. ${ }^{159}$

Even a strict application of the Aberdeen and Kleppe rule would not alter the resolution of the timing issue in this case. In contrast to what had occurred in the ICC situation in which no proposal was in existence prior to the adjudicatory hearings, the Court in Aberdeen stated that "where an agency initiates federal action by publishing a proposal and then holding hearings on the proposal, the statute [NEPA] would appear to require an impact statement to be included in the proposal and to be considered at the hearing." 160 The proposal on the Guidelines was submitted to the Director of NIH in February 1976, and a review process, tantamount to a hearing, ${ }^{161}$ was held shortly thereafter. According to the rule suggested in Aberdeen, a final EIS on the Guidelines should have been included in the proposal and available for review at the hearing. Not only did NIH not have a final impact statement ready for the February 1976 hearing, a violation of NEPA, it had yet to issue a draft EIS on the Guidelines. Moreover, a draft EIS is required by the hearing stage even in cases where a court finds, as the Supreme Court did in Aberdeen, that no final EIS was necessary until after the hearings because no "proposal" was in existence prior to that time. The Court quoted the CEQ Guidelines:

To the fullest extent possible, all . . . hearings [on proposed agency action] shall include consideration of the environmental aspects of the proposed action . . . . Agencies should make any draft environmental [impact] statements to be issued available to the public at least fifteen (15) days prior to the time of such hearings. ${ }^{162}$

The fact that the ICC in Aberdeen had issued and circulated draft impact statements before the hearings was held to be sufficient in that case to comply with NEPA. NIH did not publish its Draft EIS until August 1976, six months after the hearings on the proposed Guidelines and two months after the final Guidelines were issued.

In the introductory statement of its Draft EIS, NIH excused its tardiness by citing exigent circumstances. The Guidelines had to be promulgated before the Draft EIS was ready (and apparently before publication in the Federal Register) because of the urgent need to protect the public from the hazards of recombinant research. ${ }^{163}$ Furthermore, the decision-making process, which preceded publication of the Guidelines, was the functional equivalent of the environmental review required by NEPA. ${ }^{164}$ The claim that

159. 41 Fed. Reg. 38426 (1976).

160. 422 U.S. at 320.

161. 40 C.F.R. \& 1500.7(d) (1977).

162. 422 U.S. at 321 (emphasis in original).

163. 41 Fed. Reg. 38427 (1976).

164. Id. 
the Guidelines had to be published immediately in order to protect the public is not accurate. Prior to publication, the public was better protected by a voluntary moratorium. Publication of the Guidelines could have awaited completion of the impact statement process. Furthermore, NIH had ample time to prepare both a draft and a final EIS while the Guidelines were being drafted. Drafting began in February 1975, and was not completed until February 1976. ${ }^{165} \mathrm{NIH}$ also did not provide an adequate opportunity for public participation. Even though NEPA requires an opportunity for public and agency comment on a draft EIS before a formal proposal is made, ${ }^{166}$ the proposed Guidelines were released for comment without any prior public participation. Moreover, there was no EIS available at the time the proposed Guidelines were published. Thus, the public had no opportunity to comment on alternatives.

The values sought to be protected by NEPA are in danger of being irretrievably lost in this instance by NIH's blatant and severe disregard of its procedural requirements. Even if the Draft EIS were substantively perfect, it is too late to improve the environmental aspects of NIH's decision on DNA recombinant technology. ${ }^{167}$

\section{The Substance.}

Recombinant DNA research and technology initiates a new era of synthetic biology. Techniques for gene transplantation are not simply novel research tools, but instruments for the manufacture of new organisms. Few doubt that these techniques have the potential for deliberate misuse to produce pathogenic organisms capable of disrupting the ecosystem or initiating deadly forms of disease. ${ }^{168}$ Considering the incomplete understanding of the biological implications of novel combinations of genes, it is also

165. Id.

166. NEPA § 102(2)(C), 42 U.S.C. § 4223(2)(C) (1970).

167. Environmental groups recently filed suit alleging that NIH violated NEPA by funding recombinant DNA research without first considering environmental factors in an EIS, and by releasing the Guidelines before a draft EIS has been published for public comment in the Federal Register. Friends of the Earth v. Califano, No. 77-2225 (S.D.N.Y., filed May 9, 1977). See also Mack v. Califano, 447 F. Supp. 668 (D.D.C. 1978), denying a preliminary injunction to prevent experimental testing of biological properties of polyoma DNA cloned in bacteria cells at Fort Detrick, Md. The court upheld the vitality of the EIS's evaluation of the Guidelines and permitted the research experiments to proceed.

On September 27, 1977, NIH issued Proposed Revised Guidelines, 42 Fed. Reg. 49596 (1977). The revisions would relax some of the initial restraints on DNA research. They were drafted because of NIH's growing confidence in the security of the safety measures contained in the Proposed Guidelines, as well as research indicating that the possible dangers of the research had been greatly exaggerated. Id. 49597. Presumably NIH will issue a draft EIS on the Revised Guidelines.

168. Federation of American Scientists, Public Interest Report: Recombinant DNA 1 (Apr. 1976) (Position Paper, Document 9). 
possible that comparably disastrous effects might result from "peaceful" research and development. As in the case of other hazardous activities, the guiding principle for policy formation ought to be the well-being and security of human life. It is by this principle that NIH's actions must be analyzed.

The Draft EIS contains some expression of the primacy of public safety. The objective of the Guidelines is stated to be "the protection of laboratory workers, the general public, and the environment from infection by possibly hazardous agents that may result from recombinant DNA research." 169 The conclusion drawn by the Draft EIS is that by promulgating the Guidelines, NIH has fully satisfied that objective. According to the statement, if the Guidelines are followed, the probability that a pathogenic organism will be created is extremely low. ${ }^{170}$ Even if created, the probability of escape from its restrictive environment is equally low. ${ }^{171}$ Statements such as "any potential release of high-risk materials to the environment should be prevented by adherence to the NIH Guidelines" 172 suggests that the Guidelines have adequately taken into account all possible ways in which any potential biological hazard arising from recombinant DNA research could enter the environment, that there is little further need to improve them or to explore alternative courses of action and that the public can afford to rest easy in the well-supported blanket of protection provided by responsible science.

Yet there is nothing within the impact statement that provides a rational basis for such sanguine conclusions. On the other hand, both what is stated and omitted casts significant doubt on the validity of the impact statement. Indeed, the statement is, on the whole, in substantive noncompliance with NEPA. While the procedural directives of section 102 have received most of the judicial attention in NEPA litigation, ${ }^{173}$ it is clear that these procedures

169. 41 Fed. Reg. 38427 (1976). The Introduction continues: "The Guidelines are meant to ensure that experiments are carried out under conditions and safeguards that minimize the possibility of harmful exposure of any human being or other component of the environment to these possibly hazardous agents." Id.

170. Id.

[I]t is believed that the containment measures specified in the Guidelines make the escape of potentially harmful recombinant organisms into the environment highly improbable. . . [I]t is also believed that, even if an experiment performed in accordance with the Guidelines does result in accidental release of recombinant organisms, Id. adverse effects will either not occur or not be serious.

171. Id.

172. Id.

173. Most particularly courts have tended to focus on the sufficiency of the impact statement requirement and of the bureaucratic procedures followed in considering that statement. Presumably the reason for this focus is that these are the most concrete incidents of agency environmental considerations and hence most easily subjected to judicial evaluation. Furthermore, challenges to agency action under NEPA tend to focus on the sufficiency of the impact 
are not ends in themselves but are intended to trigger and ensure the implementation of the less precise substantive policies of environmental protection enunciated in section 101 of the Act. ${ }^{174}$ The courts have recognized that each agency has an obligation to carry out the substantive as well as the procedural requirements of NEPA and that purely mechanical compliance with section 102 is not sufficient to satisfy the provision of the Act. Furthermore, the courts will not hesitate to review substantive agency decisions on the merits. ${ }^{175}$ NEPA was intended to effect substantive results and to be more than an environmental full disclosure law.

In reviewing agency decisions on the merits, the court will examine whether the agency engaged in a full and good faith consideration and balancing of all relevant environmental factors ${ }^{176}$ and whether, in the light of the standards set forth in sections $101(b)^{177}$ and $102(1)^{178}$ of the Act, "the actual balance of costs and benefits that was struck was arbitrary or clearly gave insufficient weight to environmental values." 179 The standard of re-

statement and agency procedures for its consideration. Although a NEPA complaint will generally allege violations of each section of the Act, complainants tend to focus on the more concrete sections of the Act when filing affidavits or making formal offerings of proof of agency noncompliance with NEPA standards.

174. S. REP. No. 296, supra note 44, at 19.

175. Environmental Defense Fund v. Corps of Engineers, 470 F.2d 289, 298-99 (D.C. Cir. 1972). "NEPA is silent as to judicial review, and no special reasons appear for not reviewing the decision of the agency. To the contrary, the prospect of substantive review should improve the quality of agency decisions and should make it more likely that the broad purposes of NEPA will be realized." See also Conservation Council of N.C. v. Froehlke, 473 F.2d 664 (4th Cir. 1973); Natural Resources Council, Inc. v. Morton, 458 F.2d 827 (D.C. Cir. 1972); National Helium Corp. v. Morton, 455 F.2d 650 (10th Cir. 1971); Scenic Hudson Preservation Conference v. FPC, 453 F.2d 463 (2d Cir. 1971), cert. denied, 407 U.S. 926 (1972) (Douglas, J., dissenting); Ely v. Velde, 451 F.2d 1130 (4th Cir. 1971); Calvert Cliffs' Coordinating Comm. v. AEC, 449 F.2d 1109 (D.C. Cir. 1971). See also the third annual report of the CEQ which concludes that "after an agency has considered environmental effects, its decision to act is subject to . . limited judicial review." 3 CEQ ANN. REP., ENVIRONMENTAL QUALITY 254 (1972).

176. Calvert Cliffs' Coordinating Comm. v. AEC, 449 F.2d 1109, 1115 (D.C. Cir. 1971).

177. Agencies have an obligation "to use all practical means, consistent with other essential considerations of national policy, to improve and coordinate Federal plans, functions, programs and resources" to preserve and enhance the environment. NEPA § 101(b), 42 U.S.C. § 4331(b) (1970). To this end, section 101 sets out specific environmental goals to serve as a set of policies to guide agency action affecting the environment.

178. NEPA $\S 102(1)$, id. $\S 4332(1)$, directs that the policies, regulations and public laws of the U.S. be interpreted in accordance with these policies to the "fullest extent possible."

179. Calvert Cliffs' Coordinating Comm. v. AEC, 449 F.2d 1109, 1115 (D.C. Cir. 1971). This standard of review in its totality focuses on two main aspects of the bureaucratic process. First, a court will review agency decisions for failure to take into account all relevant factors or values or for misuse of authority in basing decisions on irrelevant factors or values. Secondly, a court will review to see that no single factor or value has been given too much or too little weight in the decision. This is in addition to the court's review of the sufficiency of bureaucratic procedures for ensuring the consideration of environmental factors. NEPA mandates a "particular sort of careful and informed decisionmaking." Id. 
view thus articulated is a narrow one in the sense that it is not within the court's power to substitute its judgment for that of the agency. ${ }^{180}$ NIH's Draft EIS fails to pass such a test.

The impact statement is not the "detailed statement," in either quantity or quality of environmental information, required by NEPA in order to fulfill its purpose of providing a basis for informed decision-making on the key question of whether recombinant DNA technology should proceed. ${ }^{181}$ The agency's conclusion that it is currently environmentally sound to proceed with recombinant DNA research and experimentation, performed as specified in the NIH Guidelines, is based on incomplete, inadequate and untested data, and is not the result of a full and good faith effort to set forth all the competing environmental considerations.

In order for the impact statement to provide rational assurance to the public that the most environmentally sound decision has been made, four general categories of information should be provided: first, a description of the proposed action, its probable environmental effects and all reasonably available alternatives; second, estimates of the likelihood and magnitude of the environmental effects of the action and of the alternatives; third, where possible to calculate, the monetary cost of such effects; and fourth, an analysis of the resultant cost-benefit balance. The complete impact study must be more than just a catalogue of the above categories of data. The agency must also "explicate fully its course of inquiry, its analysis and its reasoning." 182 The analysis must be objective.

The most significant failures of NIH's Draft EIS as a detailed, intelligent description and quantification of the probable environmental effects of recombinant DNA research, and its failures in meeting the "good, full faith consideration" test are its lack of objectivity, its unsatisfactory discussion of alternatives and its inadequate and inaccurate description and quantification of the hazards of recombinant DNA research. These individual failures contribute to the document's unfounded and highly misleading claims re-

180. Citizens to Preserve Overton Park v. Volpe, 401 U.S. 402,416 (1971). Some judges have argued for a stricter standard of review. See, e.g., Scenic Hudson Preservation Conference v. FPC, 453 F.2d 463, 482 (2d Cir. 1971), cert. denied, 407 U.S. 926 (1971) (Oakes, J., dissenting), as well as the dissent of Mr. Justice Douglas from the order denying certiorari, in which it was argued that a standard of review stricter than the arbitrary or capricious test should have been used, 407 U.S. at 930-31. Similarly, a three-judge court in City of New York v. United States, 344 F. Supp. 929, $939-40$ (E.D.N.Y. 1972), made a limited review on the merits of an agency decision. The question as to whether or not a stricter standard of review should be used was left open.

181. The Guidelines themselves, although comparatively more detailed and objective in tone than the brief conclusory Draft EIS, are nevertheless deficient in providing a rationally convincing basis for its assurances that the public is now well protected from the potential hazards of DNA recombinant technology.

182. Ely v. Velde, 451 F.2d 1130, 1139 (4th Cir. 1971). 
garding the efficacy of the containment measures outlined in the Guidelines to ensure public safety.

1. Lack of Objectivity. NIH's Draft impact statement can be characterized as an exercise in justification. Its dominant tone is adversarial, radiating an urgent sense of "let's get on with it," and its content never adequately addresses the central policy questions regarding genetic manipulation and development. As an exercise in justification, it is violative of NEPA's mandate to federal agencies to undertake major actions affecting the quality of the human environment only after a full and good faith consideration and balancing of all economic and environmental concerns. Without such a requirement, the impact statement provision of section 102(2)(C) would serve only a disclosure function and assurances that the substantive policies of section 101 would be respected would be lessened considerably. Judicial enforcement of NEPA standards requires a determination of whether the agency has reconstructed its decision-making apparatus in a way that ensures review of environmental considerations disclosed in impact statements and whether the agency has actually considered the information and analysis adduced in the statement in making its decision.

If the decision [the major action significantly affecting the quality of the human environment] was reached procedurally without individualized consideration and balancing of environmental factorsconducted fully and in good faith-it is the responsibility of the courts to reverse. ${ }^{183}$

Even the mere probability that an impact statement will, because of the selfinterest of the authors in the proposed project, be based on "self-serving assumptions" 184 is enough to render the procedure in noncompliance with NEPA.

No decision or decision-making procedure can meet the standard of

183. Calvert Cliffs' Coordinating Comm. v. AEC, 449 F.2d 1109, 1115 (D.C. Cir. 1971). This case, which involved the licensing of a nuclear power plant, indicated that NEPA requires actual and active consideration of environmental factors in agency planning, and also requires internal organization and procedures to ensure such consideration. The AEC rule in dispute in the case forbade the AEC hearing board to consider nonradiological environmental factors in reviewing applications for nuclear power plants unless such factors were "affirmatively raised" by intervenors or AEC regulatory staff. This ad hoc reliance on interested third parties to raise environmental issues was held to be insufficient to meet NEPA's requirements.

184. Greene County Planning Bd. v. FPC, 455 F.2d 412, 420 (2d Cir. 1972). FPC regulations, 18 C.F.R. $\S 2.80-82$ (1972), allowed power plant applicants to prepare their own impact statements which the FPC staff would then circulate to other federal agencies for comment. The FPC, however, would file its own impact statement only after its final decision to license the plant. Such a procedure was deemed by the court to be inadequate because it did not evidence independent FPC research and analysis nor did it provide an FPC statement for comment and debate prior to the agency's final decision. 
"full, good faith consideration" if the agency is committed in advance to a particular course of action. If the ultimate decision-maker were so committed, there obviously could be no "good faith" consideration of alternatives to the preselected course of action. Thus, the environmental costs of proceeding with the chosen course of action could not be said to have been actually "considered," but merely to have been recognized. Substantial evidence exists which indicates that NIH determined to continue the funding of recombinant DNA research prior to development of the Draft EIS and that this determination affected the objectivity of the agency's consideration of the matter. ${ }^{185}$ For example, by misdefining its "major . . . action" to be the promulgation of the safety measures contained in its Guidelines rather than its financial support of recombinant DNA research, NIH established a framework for the EIS discussion that effectively ignored the key question that the statement ought to address-whether, on balance, it is environmentally wise to proceed with widespread recombinant DNA technology. The whole impact statement discussion proceeds from the implicit assumption that it is environmentally wise and that $\mathrm{NIH}$ will continue funding such research. ${ }^{186}$ The timing of the Draft EIS, years after grants had been awarded by NIH for recombinant DNA research and when the research was fast approaching the applied technology state, as well as after the promulgation of the Guidelines themselves, is a procedural violation of NEPA and constitutes further evidence that the impact statement is nothing more than "post-hoc environmental rationalizations of decisions already fully and finally made." 187

Scientific controversy and debate have raged around the issue of recombinant DNA research and technology. The potential dangers have been likened in magnitude by many scientists to those of applied nuclear technology. The scientific community was sufficiently concerned in 1974 to impose an unprecedented moratorium on such activities. ${ }^{188}$ Responsible scientific literature on the subject is extensive. ${ }^{189}$ Yet nowhere in NIH's discussion of the biological aspects of recombinant DNA technology or of

185. This is not to suggest that the standard required by NEPA is that of subjective impartiality. "NEPA assumes as inevitable an institutional bias within an agency proposing a project and erects the procedural requirements of $\S 102$ to insure that 'there is no way [the decision-maker] can fail to note the facts and understand the very serious arguments advanced by the plaintiffs if he carefully reviews the entire environmental impact statement.' "'Environmental Defense Fund v. Corps of Engineers, 470 F.2d 289, 295 (8th Cir. 1972). Thus NEPA requires that prior to embarking on an action an agency must objectively evaluate the environmental costs and benefits and that the evaluation process be reflected in an impact statement.

186. See notes 111-19 supra and accompanying text.

187. Jones v. District of Columbia Redevelopment Land Agency, 499 F.2d 502, 511 (D.C. Cir. 1974), cert. denied, 423 U.S. 937 (1975). See notes 120-67 supra and accompanying text. 188. See notes 13-16 supra and accompanying text.

189. See materials cited in notes $1-5$ supra. 
the containment measure to safeguard experiments is reference made to the large body of scientific opinion that is in disagreement with NIH's positions. ${ }^{190}$ Indeed, very few of the claims advanced are backed up by reference to any authoritative source material. For the most part assertions are advanced in a conclusory fashion; the reader, left uncertain of their basis, is asked to accept NIH's controversial statements on little more than blind faith. An impact statement based substantially on unsupported conclusions and without reference to responsible opposing views is contrary to the objective process required by NEPA; 191 "actions" based on such a statement are arbitrary.

190. An example of this failure is NIH's discussion of the organism E. coli. The biological containment safeguards of the Guidelines depend upon the safety of the use of E. coli (strain $\mathrm{K} 12$ ) as the bacterial host. In sanctioning the use of $\mathrm{E}$. coli as a recipient for recombinant DNA molecules, it is stated that "[T]his organism has been studied extensively and is well suited to recombinant research." 41 Fed. Reg. 38435. The statement goes on to admit that "[I]t has been argued . . . that E. coli should not be used at the present time. This is because many E. coli strains are intimately associated with humans and other living things, and because they readily exchange DNA [genes] with certain other bacteria in nature." Id. No reference is given to the many scientific publications which assert in essence that there is probably a no more inappropriate organism to use than E. coli for such work. E.g. , Anderson, Viability of, and Transfer of a Plasmid from, E. coli K-12 in the Human Intestine, 255 NATURE 502 (1975). See also Chargaff \& Simring, On the Dangers of Genetic Meddling, 192 SCIENCE 938 (1976) (letter to the editor); Dyson, Costs and Benefits of Recombinant DNA Research, 193 SCIENCE 6 (1976); Hubbard, Recombinant DNA: Unknown Risks, 193 SCIENCE 834 (1976); Simring, Recombinant DNA Risks and Benefits, 192 SCIENCE 940 (1976). No relevant information on the K12 strain is given such as its rates of genetic exchange with other wild type $\mathrm{E}$. coli, or the mechanisms by which K12 could be made pathogenic through recombinant research both intentionally and unintentionally. There is no discussion of the fact that many pathogenic E. coli strains exist. For example, two out of 1000 patients that enter Boston hospitals die from E. coli infections. 294 NEW ENG. J. MED. 61 (1976). The statement made by NIH that the organism has been "extensively studied" has also been refuted. "As of October 1976, only a few experiments to test the innocuousness of $\mathrm{K} 12$ have been performed, and these under only the most normal conditions. The conditions under which accidents occur are notable for their non-normality." Lappé, Regulating Recombinant DNA Research: Pulling Back from the Apocalypse, II MAN AND MEDICINE, Summer 1976, at 103, 106. Scientists have also urged that research efforts should first be directed to the development of a host organism that is not a resident of the normal human environment and does not exchange DNA organisms in that environment. These are not referred to. In general, the hazard of using a bacteria whose niche is the mammalian gut and the possible repercussions of this are in no way discussed in an adequate, informed manner.

191. A function of the court is

to assure that the statement sets forth the opposing scientific views, and does not take the arbitrary and impermissible approach of completely omitting from the statement, and hence from the focus that the statement was intended to provide for the deciding officials, any reference whatever to the existence of responsible scientific opinions concerning possible adverse environmental effects.

Committee for Nuclear Responsibility, Inc. v. Seaborg, 463 F.2d 783, 787 (D.C. Cir.), application for injunction in aid of jurisdiction denied, 404 U.S. 917 (1971). In that case, the court agreed with plaintiff's claim that omission of all reference to existing responsible scientific opinion as to possible adverse consequences is contrary to the process described in NEPA. $C f$. Environment Defense Fund v. TVA, 339 F. Supp. 806, 809 (E.D. Tenn.), aff'd, 468 F.2d 1164 (6th Cir. 1972)(draft impact statement on the Tellico dam project insufficient because its costbenefit analysis consisted almost entirely of unsupported conclusions and requiring that a final statement be filed). 
2. The Hazards and the Safeguards. The Draft EIS offers explicit assurance that the Guidelines adequately safeguard human and environmental health, thereby implying that all potentially dangerous possibilities arising from gene transferences can be, and have been, accurately assessed and that adherence to the Guidelines will be universal. Both propositions are doubtful.

When the moratorium on DNA recombinant experimentation was called in June 1974, it was proposed to last until the potential hazards of such recombinant DNA molecules have been better evaluated or until adequate methods are developed for preventing their spread. ${ }^{192}$ Although neither of these conditions have been met, NIH has approved proliferation of the technology. Present scientific knowledge of much of the genetic function in existing organisms remains very slim; there is an even greater absence of hard facts about the risks of the infinite variety of genetic combinations that might result from recombinant gene transference. Admissions of this knowledge gap and uncertainty are found in various parts of the impact statement, as well as the Guidelines. An implicit acknowledgement can be found in the Introduction to the Draft EIS, which states: "In issuing the Guidelines, the NIH Director pointed out that they will be subject to continuous review and modification in the light of changing circumstances." ${ }^{193}$ More explicit admissions exist in the impact statement:

Current knowledge does not permit accurate assessment of whether such changes [in the properties of the host cell or virus from the stable insertion of DNA derived from a different species] will be advantageous, detrimental or neutral, and to what degree, when considering a particular recombinant DNA experiment. At present it is only possible to speculate on ways in which the presence of recombinant DNA in a cell or virus could bring about these effects. ${ }^{194}$

The Draft impact statement is laced with optimistic predictions based on these admittedly uncertain data and untested theories. A few of the more significant statements are illustrative.

A central assumption of the EIS is that if the physical and biological

192. See Berg, Baltimore, Brenner, Roblin \& Singer, supra note 16, at 1984.

193. 41 Fed. Reg. 38427 (1976).

194. Id . 38429. Other admissions are: "In the absence of an adequate base of data derived from either experiments or experience, it must be recognized that future events may not conform to these judgments [the Guidelines containment levels]." Id. 38427. "Different assessments of the hazards could have been made and consequently more stringent precautions could have been taken." Id. "[T] he use of these physical containment] measures reduces but does not prevent the potential for laboratory-acquired infections." Id. 38436. "Lack of knowledge about the real risks of such molecules makes it impossible to determine either the nature of the hazards or the extent to which laboratory personnel are endangered by exposures to the materials." Id. 
containment measures of the Guidelines are strictly observed in DNA experiments, hazardous organisms will not be created (biological containment), or that if they are created, they will not escape from laboratories (physical containment), and that an acceptable degree of safety has thereby been provided. There is, however, no realistic assurance that the system devised is scientifically sound. The system for classifying experiments as outlined in the Guidelines is elaborate. ${ }^{195}$ A given experiment is assigned to a category according to the type of recombinant DNA involved. It is then assigned to one of four physical containment levels and one of three biological containment levels. ${ }^{196}$ Extremely hazardous experiments are prohibited outright. ${ }^{197}$ The physical containment measures describe laboratory conditions ranging from "Pl" to "P4," with $\mathrm{P} 4$ being the most restrictive and also the most expensive to construct and operate. ${ }^{198}$ It is assumed and considered to be within the range of acceptable risk that a certain amount of accidental release will occur in P1 and P2 facilities. ${ }^{199} \mathrm{NIH}$ assumes that because only organisms which have been rated low or moderate risks are handled in $\mathrm{P} 1$ or $\mathrm{P} 2$ laboratories, such exposure will not harm laboratory workers or others. ${ }^{200}$ The biological containment provisions are based on the theory that certain organisms carry a greater potential for toxic spread and contamination than others and therefore require a more secure laboratory. ${ }^{201}$

Although the complexity of the containment system is impressive, the repeated admissions by NIH that it does not know enough about the hazards of recombinant DNA and the effects of any particular genetic recombination make highly doubtful the accuracy of the risk evaluations on which the 13tiered classification of containment levels is premised. There is no scientific evidence for the assumption that organisms which are rated low-risk by NIH's classification system will prove harmless. For example, the central assumption underlying the biological classification system and the biological containment measures is that most cells with foreign DNA from higher organisms are more hazardous than those from lower organisms. Therefore, more containment is required for experiments that take DNA from primates than for those that take DNA from birds or plants. ${ }^{202}$ But there is no scientific basis for assuming that philogenic order or any other single factor

195. The system is only superficially noted in the Draft EIS itself. Id. 38432-34.

196. Id. 38456-57.

197. Id. 38454.

198. Id. 38452-54.

199. In describing the protection provided by $\mathrm{P} 1$ and P2 facilities, the Draft EIS states: "These measures to not provide absolute protection from exposures, and the required primary barriers can be compromised by lack of attention to technique, poor placement of equipment, and human error." Id. 38436.

200. Id.

201. Id. $38452,38454$.

202. Id. 38454-58. 
can accurately predict risk ${ }^{203}$ when the Draft EIS itself lists thirteen factors that determine the likelihood that a particular organism will cause harm. ${ }^{204}$ Whatever single factor is selected to rank hazards, it will always be possible to make a credible argument that some experiments which are rated as low risks are in fact more risky than some of those that were rated as high risks.

The larger question of whether there can ever be any biological containment is never addressed by the EIS. Even if a disabled strain-one that could not survive outside the laboratory-were developed, we could never be sure of its safety because, by definition, a recombinant experiment would add new traits to the disabled strain that might cancel out its disability. ${ }^{205}$ The EIS itself presents a good example of just this phenomenon. It describes an experiment in which an histidine deficient $\mathrm{E}$. coli (a disarmed host) lost its disability when recombined with yeast DNA. ${ }^{206}$ Since after recombination a new organism is developed, the premise of biological containment is possibly an invalid one. ${ }^{207}$

203. It is possible to imagine an experiment with primate DNA which is less hazardous than one with prokaryote DNA. For example, an experiment that puts primate DNA into E. coli might produce an organism with such a low probability of survival and such a low probability that the primate DNA would be fully expressed and create a primate protein, that it poses virtually no risk to humans. Another experiment in which DNA from a prokaryote is inserted in E. coli might improve the survival ability of E. coli, be transmitted to a pathogenic strain of $E$. coli and make it more virulent, thereby substantialiy increasing the risk of disease in humans. Some of the assumptions underlying the classification system are contradictory. In some situations higher containment levels are required because almost nothing is known about the hazards; in other situations, stricter containment is required because concrete information about the hazards exists. For example, one of the reasons for requiring a high level of containment for experiments with primate DNA is that we know so little about such recombinations. On the other hand, the reason for prohibiting experiments which would transfer antibiotic resistance to nonresistant species is that we know such transfers will certainly impair the ability to cure human disease. Similarly, special provision is made in the Guidelines for experiments using $\mathrm{E}$. coli host-vector systems because we know that $\mathrm{E}$. coli colonizes in the human intestine. But other prokaryotic host-vectors, which do not colonize in humans, may prove equally harmful to the environment in ways we cannot now foresee.

204. The EIS walks the reader through a complex series of hypothetical events which would have to happen simultaneously to create a biohazard. The gentically engineered organism which possesses a potentially harmful gene must first escape from the experimental situation (risk: 1 in 100); it must survive after escape (risk: 1 in 10,000); it must grow and reproduce in its new environment (risk: 1 in a million). Successful epidemic conditions would then require that the first infected organisms contact other hosts, that the bacteria leave the first host in infectious form, and grow and multiply once again. The aggregate risk (which the authors consider conservative) is given as 1 in a trillion $\left(1 \times 10^{12}\right) .41$ Fed. Reg. 38438 (1976).

205. The very brief discussion on the ideal use of a strain of bacteria that could not survive outside of the laboratory does not in any sense serve as a real discussion on the important area of biological containment. Id. 38432-33, 38435.

206. Id. 38430.

207. Other problems with biological containment which should have been discussed in the EIS include the possibility that the biologically enfeebled host organisms could spontaneously 
Because the likelihood of harm cannot be calculated with precision, the Guidelines essentially provide for the ranking of experiments on the basis of untested theories which may be inaccurate or not comprehensive enough to be used as the basis for predicting risk. Since recombinant DNA molecules are placed in living host cells, which have the potential of surviving and multiplying in the environment, even one experiment that is mistakenly considered harmless could cause widespread and irreversible damage. Given the magnitude of possible adverse impacts and the imprecision of present estimates of risks of different experiments, all organisms should be presumed hazardous to the environment if they should escape. Although some recognition of this presumption and incorporation of cautionary measures can be found in the impact statement, the overall effect of NIH's action is to promote the proliferation of the number of facilities engaged in gene transplantation and to create a false sense of security by using sweeping, unsupported generalizations that consistently downgrade the estimates of the potential risks. Such a statement as "[T] a hazardous agent has been created by recombinant DNA technology" 208 is typical. Given the fact that a moratorium has been in effect since 1974, and that this area of scientific inquiry is not even seven years old, this statement is less elucidating on the point of safety than it might appear. ${ }^{209}$ The same statement would have applied to uranium enrichment prior to the summer of 1945 when the first nuclear bomb was actually tested.

revert to a wild type organism, or could survive and propagate by otherwise circumventing the disabling characteristics forced upon it. Another possibility that was never addressed in the Draft EIS is that since the crippled organism will grow more slowly due to its disability a contaminant might fall into the culture and grow at a faster rate than the disabled organism. Thus, the researcher will unknowingly end up with a culture not of the disabled host, but of a wholly different viable organism. Another potentially hazardous situation would occur if a nonpathogenic culture became contaminated with a virulent species. The researcher could continue to treat it as harmless, subjecting it to the stricter containment care it should receive. No periodic check for culture purity is recommended in the impact statement or the Guidelines. The Guidelines should require a continual checking of host organisms to ensure that they always contain the full complement of disabling characteristics. See Comments of Hon. Louis J. Lefkowitz, Atty. Gen. of N.Y., on the Guidelines and Draft EIS for Recombinant.DNA Research, Submitted to the Director of NIH, at 11-12 (Oct. 19, 1976).

All of the above mentioned problems and limitations of biological containment should have been thoroughly discussed. An extensive review of microbiological strategies whereby host organisms could lose their disabling characteristics, plus a risk analysis of the likelihood of this happening, is an essential requirement for an adequate impact statement.

208. 41 Fed. Reg. 38429 (1976).

209. The possibility of the totally unexpected is emphasized in the impact statement's discussion of "Benefits," but is not addressed adequately in the discussion of "Hazards." In discussing potential benefits, it is stated: "It is important to stress that the most significant results of this work, as with any truly innovative endeavor, are likely to arise in unexpected ways and will almost certainly not follow a predictable path." Id. 38431. Similar statements could be made about the hazards. For example, an organism containing chimeric DNA could possess properties exhibited by neither the host nor the organism providing the source of the recombinant DNA. 
A policy formulation premised on the presumption that, given the absence of hard data, all organisms with DNA must be considered hazardous would confine all research to one or a few heavily secured facilities until the dangers could be more accurately assessed. ${ }^{210}$ The research efforts should be directed to the determination of the nature and level of the risks inherent in gene transplantation, the development of a host organism that is not a resident of the normal human environment and does not exchange DNA with organisms in that environment, and the determination of the effectiveness of biological containment with this new host organism. ${ }^{211}$

Human safety cannot be compromised. The implicit framework of the impact statement discussion appears to revolve around the question of whether the Guidelines balance scientific responsibility to the public with scientific freedom to pursue new knowledge. Presentation of the issue as one of "balancing" suggests the propriety of a compromise between the two-a misleading and dangerous position. With a process that has such a high level of possible risks, the only concern that cannot be compromised is public safety. If that means a longer wait for benefits while procedures for better identifying potential risks and for preventing their occurrence and spread are developed, it is a small price to pay.

Furthermore, NIH's implicit expectation that its Guidelines will

210. The experience with atomic energy provides an example of how unrealiable future risk predictions can be. When the decision was made in 1941 to proceed with the technology, very little was known about the biological effects of radiation, particularly low level effects. DNA had just been discovered; the mechanism of mutation was unknown. The designers of the Bomb knew that $E=M C^{2}$, but did not anticipate radioactive fallout from the atmosphere as more than a trivial problem. "Allowable" exposures to radiation were many times higher than the current $5 \mathrm{rem} /$ year, itself under much attack for being too high. No one imagined, or cared, that plutonium would turn out to be a potent carcinogen. In short, all the hazards, the undesirable effects and "environmental impacts" of the governmental action to develop atomic energy have been much worse than anyone imagined in 1941. The benefits (if this term can be legitimately used), including nuclear power, were fairly well anticipated in 1941. Hearing Before the Subcomm. on Health and Scientific Research of the Senate Comm. on Human Resources, 95th Cong., 1st Sess. 259-60 (1977) (comments of Burke K. Zimmerman, Ph.D., Staff Scientist, Environmental Defense Fund, on the Draft Environmental Impact Statement for the NIH Guidelines for Research Involving Recombinant DNA molecules submitted to the Director of NIH (Oct. 18, 1976)). Thus the history of nuclear energy undermines the Draft impact statement which implies that we know enough about the potential hazards so that "strict adherence" to the Guidelines should render "harmful effects from research with high risk recombinant DNA molecules . . . extremely unlikely." 41 Fed. Reg. 38437 (1976). Such a statement cannot be justified in the context of DNA research.

211. The experience with the use of radioactive materials in the laboratory, an area under strict government regulation, reveals that a number of abuses occur for a variety of reasons. The situation is somewhat different with DNA recombinantresearch because radioactivity, if released, is diluted in the environment, while an organism capable of survival and reproduction could multiply and spread. See Hearing Before the Subcomm. on Health and Scientific Research of the Senate Comm. on Human Resources, supra note 210, at 268-69 (comments of Burke K. Zimmerman, Ph.D.). 
command universal adherence is unrealistic. The Guidelines expressly regulate only NIH grantees, calling for voluntary compliance on the part of other researchers. ${ }^{212}$ Thus far the call for voluntary compliance from private institutions and industry has been less than resounding; there is little realistic expectation that this will change. ${ }^{213}$ Only the National Science Foundation (NSF) has given its formal commitment; the pharmaceutical industry has, in principle, agreed to abide by the safety measures, but it has been unwilling to give teeth to its commitment by disclosing all of its activities ${ }^{214}$ to the public (or competitors), citing a claimed need to protect marketing and patent information..$^{215}$

An unsettling paradox becomes apparent here. DNA research conducted under the auspices of NIH and NSF is more likely to be motivated by scientifically pure reasons than that of private industry where the desire for profit and the competition for lucrative patents might tempt scientists to dispense with the extra time, effort and care necessary to conduct experiments according to the Guidelines.

Because the "strict" adherence 216 upon which NIH's predictions are implicitly premised is unlikely to materialize, the optimistic "environmental impact" statement is misleading. The EIS would be improved by a discussion of the environmental impact of DNA research conducted without the biological and physical restrictions described in the Guidelines. To state, as does the Draft EIS, that an analysis of such unknown quantities is "speculative and therefore not quantifiable"217 is somewhat disingenuous in light of the fact that any discussion of potential risks and benefits in this field is equally uncertain. Yet this did not deter $\mathrm{NIH}$ from concluding that its Guidelines sufficiently protect our environmental well-being.

212. The impact statement points out that it is currently impossible to assign specific probabilities to events related to risk assessment and that NIH is supporting research designed to improve this deficiency. 41 Fed. Reg. 38436 (1976).

213. As discussed earlier at notes 118-19 supra, NIH made a decision not to regulate nonNIH supported techniques even though the Secretary of HEW has the authority under Section 361 of the Public Health Services Act, 42 U.S.C. $\$ 264$ (1970), to regulate all such activities.

214. Experiments conducted in violation of the Guidelines will pose the same hazards as experiments which are not covered by the Guidelines. The Draft EIS should, but does not, evaluate the likelihood that the Guidelines will be followed by non-NIH grantees and the risk to the public from noncomplying experiments.

215. The presumed requirement of secrecy is in conflict with the spirit and letter of the Guidelines under which all projects require, at the very least, an impartial peer review as well as scrutiny by an institutional biohazards committee. Moreover, the implications of this industrial attitude are antithetical to the notion that any form of research and technology with a potential for impairing the health of the environment should proceed only with the informed consent of the public. Grobstein \& Clifford, Recombinant DNA Research: Beyond the NIH Guidelines, 194 SCIENCE 1133, $1133-35$ (1976).

216. 41 Fed. Reg. 38437 (1976).

217. Id. 38446. 
There is an additional reason to doubt that the Guidelines will provide sufficient protection. For the Guidelines to be as effective as NIH assures us they are, it must be assumed that the restrictive measures contained therein can be, and will generally be, implemented without consequential human and technological error-a questionable premise. Moreover, the Draft EIS does not discuss the "impact" of such potentialities. The need to do so is particularly striking when one considers the admitted lack of scientific certainty surrounding the concept of biological containment in general and the soundness of the biological and physical containment measures of the Guidelines in particular, ${ }^{218}$ and the potentially grave consequences of even one error. The fact that potentially hazardous biological materials or infectious agents are insidious makes the need even more urgent. The presence of such agents can be detected only when they are properly labelled and one has a thorough knowledge of what has taken place in the laboratory. They cannot be detected by the five senses. ${ }^{219}$ Despite this, no mention is made in the EIS of specific training or protection of the personnel handling these agents, which would be required to ensure the safe operation of the facility.

The Draft EIS assures us that "[a]ny potential release of high-risk materials to the environment should be prevented by adherence to the NIH Guidelines." 220 In support of this claim, brief reference is made to the supposed success of similar containment measures at Fort Detrick, the U.S. Army's biological warfare facility. ${ }^{221}$ Nonetheless, there is substantial support for the view that NIH's interpretation of the Fort Detrick experience is not accurate and that the more favorable experience of recent years at the Fort Detrick installation is the consequence principally of the development of means of vaccinating the personnel against the agents under study, rather

218. See notes 195-201 supra and accompanying text.

219. See Oversight Hearing on Implementation of NIH Guidelines Governing Recombinant DNA Research: Joint Hearings Before the Subcomm. on Health of the Senate Comm. on Labor \& Public Welfare and the Subcomm. on Administrative Practice and Procedure of the Senate Comm. on the Judiciary, 94th Cong., 2d Sess. 115 (1976) (comments of Burke K. Zimmerman, Ph.D., Staff Scientist, Environmental Defense Fund).

220. 41 Fed. Reg. 38437 (1976). The statement continues:

All high-risk materials are required to be isolated in physically contained, absolute primary barriers. All effluents from these barriers are sterilized. The barriers themselves are located in maximum-security facilities, which are provided with additional barriers to prevent any accidental release. Air locks, negative air pressure, clotheschange rooms, filtration and incineration of all air exhausted from the facility, and the secondary sterilization of all liquid and solid wastes, provide additional protection to Id. the environment.

221. Id. "An analysis- of 36 reported laboratory-acquired micro-epidemics in the period 1925-1975 involving over 1,000 infections . . . demonstrated no infections among persons who were never in the laboratory building or who were not associated in some way with the laboratory." The citation given by NIH is Wedum, A.G., The Detrick Experience as a Guide to the Probable Efficacy of P4 Microbiological Containment Facilities for Studies on Microbial Recombinant DNA Facilities (1976) (Unpublished Report to the National Cancer Institute). 
than, as NIH contends, the development of more effective containment facilities. ${ }^{222}$ Moreover, the impact statement adds that those infections that did occur at Fort Detrick occurred as a result of the "absence of genuine efforts to control contaminated air, liquid wastes, refuse and laundry." 223 If "genuine efforts" can be lacking in a national biological warfare facility dealing with known pathogens, it is unrealistic to expect that such efforts be made in hundreds of gene transplantation laboratories across the country when the risks are unknown to those engaged in the research.

The element of human error can never be eliminated. Mistakes are made under even the most ideal of conditions; nature is more complex and we are more fallible than we realize. The participants in the Asilomar Conference acknowledged this:

Stringent physical containment and rigorous laboratory procedures can reduce but not eliminate the possibility of spreading potentially hazardous agents. Therefore, each investigator bears a responsibility for determining whether, in his particular case, special circumstances warrant a higher level of containment. ${ }^{224}$

There is no guarantee therefore, even if the Guidelines are in effect, that a recombinant molecule will not escape the laboratory. Reported laboratory infections among scientists who work in containment facilities reveal that only a limited protection is provided to scientific workers. ${ }^{225}$ Neither the NIH Guidelines nor the Draft EIS satisfactorily acknowledge the element of human error or incorporate it into their risk equations. ${ }^{226}$

A particularly critical factor in determining the possible harm to the public, not considered in the impact statement, is the number of facilities engaged in gene transplantations. To allow, or actually promote, the proliferation of DNA research centers, as the Guidelines do, is to create a push for new discoveries, causing greater numbers of laboratory personnel to become involved in research and increasing the likelihood of laboratory accidents resulting from human and mechanical failures. Such proliferation negates the effectiveness of the proposed physical containment procedures. Even if the Guidelines were ideal, it is unrealistic to hope that the ideal will be universally attained in hundreds of institutions across the country. Because of these factors, research should presently be confined to one national

222. See, e.g., Oversight Hearing on Implementation of NIH Guidelines Governing Recombinant DNA Research, supra note 219 , at 76-88 (comments of Dr. Robert L. Sinsheimer).

223. 41 Fed. Reg. 38437 (1976).

224. Berg, Baltimore, Brenner, Roblin \& Singer, supra note 16, at 1982.

225. See Conference on Biohazard in Biological Research 59,331 (A. Hellman, M. Oxman \& R. Pollack eds. 1973).

226. Instead, conclusions are drawn on the basis of qualified statements expressing the ideal-that under standardized procedures research personnel will be well-trained and proficient. 41 Fed. Reg. 38437 (1976). To assume this level of perfection in all cases is unrealistic. 
facility. Public safety is incompatible with the present policy of proliferation, which appears to protect the research to a much greater extent than it protects the human environment.

Additionally, the mechanisms for enforcing the Guidelines are insufficient to ensure the high level of compliance and error-free performance on which the safety predictions of the Guidelines are implicitly based. Obviously, the enforcement provisions are directly applicable only to NIH granteees. Others comply with the Guidelines voluntarily. Under the Guidelines, grantees are essentially allowed to police themselves. The chief responsibility for enforcement rests with the principal investigator, the individual or the institution under the grant, and on the "biohazards committee," which is required to be established by the principal investigator. The principal investigator is specifically responsible for evaluating the biohazards of the experiments, training staff and ensuring compliance with safety procedures. The biohazards committee of the institution must certify to the NIH staff that the experiment and facility comply with the Guidelines. ${ }^{227}$

The role and responsibilities of the NIH staff are so extensive that it is unrealistic to expect that they will have both the time and resources sufficient to adequately ensure universal compliance with the Guidelines. 228 Given the increasing number of NIH grantees currently conducting DNA research, the time demands on the staff will prevent the effective monitoring of the hundreds of facilities, as well as the safety of laboratory workers for "leaks" of recombinant DNA particles. ${ }^{229}$ Because of the number of complex factual determinations the staff is required to make, ${ }^{230}$ virtually all of its time is likely to be spent reviewing applications. The task of monitoring is made even more difficult because the Guidelines do not limit the number of facilities where recombinant DNA research can be conducted. The only sanction for noncompliance is revocation of denial of a grant; there is no force of law behind the Guidelines, no penalties are assessed even if they are deliberately flouted.

227. The EIS's discussion of Enforcement appears at 41 Fed. Reg. 38458-60 (1976).

228. The staff is also required to make a number of factual determinations: assigning containment levels, approving applications for lower containment levels, approving host-vector systems for biological containment and approving large scale experiments. Id. 38459 .

229. No truly reliable means seem to exist for detecting or giving warning of accidental release to the environment of potentially hazardous materials. Nor is there sufficient discussion on environmental-spill contingency plans. See discussion of risks, HOUSE COMM. ON SCIENCE \& TECH., supra note 15, at 36-39. See also Oversight Hearing on Implementation of NIH Guidelines Governing Recombinant DNA Research, supra note 219, at 115 (comments of Burke K. Zimmerman, Ph.D., Staff Scientist, Environmental Defense Fund). This is true when the "hazard or potential hazard cannot be seen, heard or smelled." Id. 123.

230. See 41 Fed. Reg. 38459 (1976). For the number of NIH grantees conducting DNArelated research, see note 90 supra. 
Grantees cannot be expected to police themselves effectively. There will always be a strong competitive interest in pushing research ahead and when the progress of research conflicts with adherence to the Guidelines, safety procedures may be bent. The competitive pressures on NIH grantees will be particularly great because non-NIH researchers are not subject to any mandatory safety restraints. Thus, the conclusions of the EIS regarding the nature and extent of the potential hazards of DNA research and technology and the degree of protection afforded by the promulgation of the Guidelines are not sufficiently supported by reason or authority either to be convincing or to meet the rigorous procedural and substantive standards of NEPA.

3. Inadequate Analysis of Alternatives. The Draft EIS issued by $\mathrm{NIH}$ is seriously deficient in its analysis of the many important alternatives to recombinant DNA technology. To suggest that the statement fulfills its function of providing a comparative basis upon which significant policy planning decisions can be made is to strain credulity to the breaking point. The cursory treatment given the "alternatives" raises grave question as to whether any options besides the Guidelines were ever actually weighed by NIH. Section 102(2)(E) of NEPA requires that the agency "study, develop, and describe appropriate alternatives to recommended courses of action in any proposal which involves unresolved conflicts concerning alternative uses of available resources." 231 This provision follows and adds to the requirement that alternatives to the proposed action be included in the environmental impact statement, which is found in section 102(2)(C). ${ }^{232}$ Since it has been seen to be the "essence and thrust of NEPA that the pertinent statement serve to gather in one place a discussion of the relative environmental impact of alternatives," 233 it would seem that the more extensive treatment of alternatives required by section $102(2)(D)$ should be incorporated in the EIS.

The requirements that the impact statement be "detailed," that it include an assessment of the environmental costs weighed against the expected benefits and that it outline all alternatives that would affect the cost-benefit balance are intended to ensure that agency decision-makers incorporate environmental values into their ultimate decisions and that the public has a basis for evaluating the decision. The legislative history indi-

231. NEPA § 102(2)(E), 42 U.S.C. \$ 4332(2)(E) (Supp.V 1975); see Comment, NEPA-The Purpose and Scope of the Duty to Discuss Alternatives, 7 URB. L. ANN. 390 (1974).

232. NEPA \& 102(2)(C), 42 U.S.C. \& 4332(2)(C) (1970).

233. Natural Resources Defense Council v. Morton, 458 F.2d 827, 834 (D.C. Cir. 1972). In that case the court affirmed the district court's action in enjoining the sale of oil leases in excess of $\$ 500$ million, based upon an alleged failure of the government to discuss certain alternatives in its Final EIS. 
cates the importance of alternatives as a source of environmental input into the process:

[T] he agency shall develop information and provide descriptions of the alternatives in adequate detail for subsequent reviewers and decision makers, both within the executive branch and the Congress, to consider the alternatives along with the principal recommendations. ${ }^{234}$

In addition, the Guidelines issued by the Council on Environmental Quality indicate the importance of adequately analyzing alternatives:

A rigorous exploration and objective evaluation of alternative actions that might avoid some or all of the adverse environmental effects is essential. Sufficient analysis of such alternatives and their costs and impact on the environment should accompany the proposed action through the agency review process in order not to foreclose prematurely options which might have less detrimental effects. ${ }^{235}$

To fulfill the mandates of NEPA, the impact statement study should not just list the alternatives but should also include the result of the agency's own investigation and evaluation of alternatives so that the reasons for the choice of a course of action are clear. The complete impact study must contain more than a mere catalogue of environmental facts. The agency must also "explicate fully its course of inquiry, its analysis and its reasoning." 236

NIH's discussion of alternatives fails to comply with NEPA by failing to mention many of the important alternatives to DNA research and technology and discussing others only superficially. ${ }^{237}$ The alternative options, discussed in less than ten pages of double-spaced standard sized paper, include: no action, NIH prohibition of funding of all experiments with recombinant DNA, development of different Guidelines, no Guidelines but NIH consideration of each project on an individual basis before funding, and general federal regulation of all such research. Each is hardly noted; the average length of the comments on each option is one page.

General federal regulation is mentioned, for example. An incomplete list of agencies with potential authority to regulate DNA technology is pro-

234. S. Rep. No. 296 , supra note 44 , at 21.

235. 36 Fed. Reg. 7724-25 (1971).

236. Ely v. Velde, 451 F.2d 1130, 1139 (4th Cir. 1971) (agency in question was the Law Enforcement Assistance Administration).

237. We reject the implication of one of the Government's submissions which began by stating that while the Act requires a detailed statement of alternatives, it "does not require a discussion of the environmental consequences of the suggested alternative." A sound construction of NEPA. . . requires a presentation of the environmental risks incident to reasonable alternative courses of action.

Natural Resources Defense Council v. Morton, 458 F.2d 827, 834 (D.C. Cir. 1972) (citation omitted). 
vided, ${ }^{238}$ but there is no real discussion of the form such regulation might take, nor are comparisons made between the statutory powers of these agencies, where it is noted, for example, that the Occupational Safety and Health Administration (OSHA) has authority to proscribe laboratory conditions, it is not noted that OSHA is powerless to regulate transportation of recombinant materials. ${ }^{239}$ The no action alternative, defined by NIH as continuation of NIH-funded experiments without any restrictions or controls, should more properly address itself to terminating federal governmental financial support for all recombinant DNA research. The Draft impact statement should apply not only to NIH's funding of genetic research but to all federal agency activities in this area; NIH is merely acting as the lead agency for purposes of NEPA. Recombinant research supported by other federal agencies should therefore also be discussed and evaluated in the Draft impact statement. Additionally, the no action alternative does not discuss the impact that cessation of NIH funding of genetic technology would have on the environment; it only describes the impact it would have on American research in the field.

The alternatives of issuing national safety standards regulating the conduct of all DNA research is not adequately discussed, despite the fact that HEW has the authority to issue such standards. ${ }^{240}$ The alternative of developing regional containment facilities designed to keep the experimentation away from areas of high population density was included, but the increase in safety that such a policy would offer was not discussed. ${ }^{241}$ The possibility of confining all federally funded research to one central, highly secure facility while potential hazards and the means to control them are more carefully assessed is not considered, nor is the possibility of a temporary moratorium covering federal, state and private research discussed. Also absent from the EIS are the options of maintaining a federal monopoly over recombinant DNA activities, such as exists in the case of nuclear weapons. research and manufacture, and establishing international control over DNA research utilizing multilaterally supervised sites, as was done in recent initiatives toward supernational uranium fuel enrichment and reprocessing facilities. ${ }^{242}$

238. The agencies include the Center for Disease Control and the Occupational Health and Safety Administration. 41 Fed. Reg. 38436 (1976).

239. Id.

240. Section 361 of the Public Health Services Act, 42 U.S.C. \& 264 (1970), gives the Secretary of HEW the authority to promulgate regulations to protect the public from communicable diseases. The draft EIS repeatedly recognizes that DNA activities may create or increase the virulence of infectious agents, making regulation under section 361 appropriate.

241. 41 Fed. Reg. 38435 (1976).

242. These latter choices appear certain to grow in public favor. The widespread publicity which followed the mysterious outbreak of "Legion fever" in Pennsylvania, the first instance of disease which implicates recombinant organisms, will probably result in the rapid imposition 
The Draft EIS makes no attempt to do a cost-benefit analysis as required by NEPA. ${ }^{243}$ Not one of the alternatives is weighed in a serious manner. Each course of action will have its own environmental risks and benefits and its own monetary costs. For example, because of their significant expense, it is imperative that an analysis be done on the costs of having multiple P3 and P4 containment laboratories throughout the country. This cost would probably weigh heavily toward establishing regional centers. Other factors will favor different alternatives, but they should at least be the subjects of thorough analyses. In addition to analysis of the environmental considerations of funding DNA recombinant technology, the impact statement should consider the key question of how NIH may best advance its goals of preventing and curing disease. These are the principal benefits which may possibly be achieved through DNA research. But alternative methods of accomplishing these objectives may be less expensivemonetarily and environmentally. If so, the dispersion of grants should reflect these factors. The information provided on alternatives is not minimally sufficient to permit a reasoned choice of options so far as environmental aspects are concerned. NIH has not taken the "hard look" at the environmental consequences of this significant new technology it is helping to create.

\section{CONCLUSION}

The DNA recombinant research controversy is a classic illustration of the law's inability to keep up with the pace of scientific inquiry. NIH's draft environmental impact statement, assessing its research Guidelines for the conduct of experiments relating to a technology already in the applied state of development, is a legal formality offered only to justify a fait accompli. A more far-reaching and fundamental flaw is NIH's failure to consider in its EIS the question of whether it is appropriate to fund DNA research at all. Given the potential for catastrophic harm to humankind inherent in this technology, this question should have been addressed at the outset. Since NIH has proven ineffective in regulating the pace and scope of the genetic research which it funds, separate legislation will be needed to protect the

of general federal regulation. The next serious outbreak may well precipitate federal monopoly, and the next, internationalization. Detailed planning for the possible implementation of these likely steps should begin now, lest proliferation of techniques, apparatus materials and knowhow make their later achievement extremely difficult. Early institution of arrangements congruent with the assumption of high hazard will avoid the possibilities of calamitous health damage, political overreaction and resultant expensive modification or scrapping of facilities adjudged no longer acceptable. See, e.g., Atomic Energy Act of 1954, 42 U.S.C. $\$ \S 2131-2140$ (1970) (as amended) (licensing the use of atomic energy). Legislation to regulate recombinant research, covering the private sector, was proposed in the 95th Congress. See note 244 infra.

243. See Comment, Cost-Benefit Analysis in the Courts: Judicial Review Under NEPA, 9 GA. L. REv. 417 (1975). 
public interest. Several bills are now pending in Congress, ${ }^{244}$ but, because of the powerful scientific lobby, the likelihood of any forceable action is doubtful. ${ }^{245}$ Since this is a highly technical field, and as has been noted, most legislators are "technically illiterate," 246 it will not be an easy task to develop appropriate legislative safeguards in an area in which the scientific community is divided. In the meantime, strict adherence to NIH's research guidelines is mandatory. In addition, while Congress debates the appropriate mode of regulating genetic engineering, it should at the very least codify the guidelines so that they will apply with equal force to the private and commercial sector not receiving federal research monies. The quality of life, in the final analysis, is more important than the unfettered sanctity of scientific inquiry.

244. S. 1217, 95th Cong., 1st Sess., 123 Cong. REc. S 5335-37 (daily ed. April 1, 1977) (Kennedy D-Mass.) ("The Recombinant DNA Regulation Act"); H.R. 4232, 95th Cong., 1st Sess. (1977) (Solarz D-N.Y.) ("Commission on Genetic Research and Engineering Act of 1977"); H.R. 7897, 95th Cong., 1st Sess. (1977) (Rogers D-Fla.) ("A Bill to Amend the Public Health Services Act"').

245. See Cohn, Scientist Lobby Successful- DNA Research Control Dims, Washington Post, Sept. 28, 1977, at A-1, cols. 1-2. See also Fields, Opposed by Scientists-Kennedy Withdraws Bill to Regulate DNA Research, Chronicle of Higher Educ., Oct. 3, 1977, at 10, cols. 1-5. See generally Morgenthau, Modern Science and Political Power, 64 ColUM L. REv. 1386 (1964).

246. See Ethyl Corp. v. EPA, 541 F.2d 1, 67 (D.C. Cir.) (en banc) (concurring opinion, Bazelon, C.J.), cert. denied, 426 U.S. 941 (1976) (referring to judges). 